\title{
13. Asır Misyoner ve Oryantalistlerinden William of Tripoli'nin Hz. Peygamber ve Kur’an Hakkındaki Görüşlerinin Tahlil ve Tenkidi
}

\section{Sabri ÇAP*}

\begin{abstract}
Öz: 13. asır, Batı'nın haçlı seferleriyle birlikte Müslümanlara karşı misyonerlik faaliyetlerini artırdığı bir dönemdir. Bu maksatla Arapça bilen misyonerler İslâm dünyasına gönderilmiş ve İslâm dininin iyi bilinmesi bir zorunluluk olarak görülmüştür. William of Tripoli (ö. 1277), 13. asırda Doğu'da yaşamış olup İslâm ve Hz. Peygamber hakkında eser yazmış kişilerden biridir. Bu makalede, William of Tripoli'nin İslâm ve Hz. Peygamer hakkında Latince olarak kaleme aldığı Notitia de Machometo (Muhammed Hakkında Bilgi) ve De statu Sarracenorum (Müslümanların Durumu) adlı iki eseri çerçevesinde onun Hz. Peygamber ve Kur'an hakkındaki değerlendirmeleri ele alınacaktır. Amacımız, 13. asırda Doğu'da Müslümanlara yakın bir ortamda yaşamış birinin eserlerinden hareketle Kur'an ve Hz. Peygamber'e bakışını ve bunun Batı'da Hz. Peygamber imajının oluşmasındaki etkilerini ortaya koymaktır. William of Tripoli'nin başka yazarlarda görülmeyen bazı farklı görüşleri bulunmaktadır. Onun Kur'an veya Hz. Peygamber hakkında basit bilgi hataları ve birbiriyle çelişen görüşleri mevcuttur. William'ın ileri sürdüğü bazı iddiaları ise Batı kaynaklarında tekrarlanmamıştır.
\end{abstract}

Anahtar Kelimeler: Hadis, Hz. Muhammed, Oryantalizm, William of Tripoli, Kur'an.

\section{Analysis and Criticism of the $13^{\text {th }}$ Century Missionary and Orientalist William of Tripoli's Views on the Prophet Muhammed and the Quran}

\begin{abstract}
The $13^{\text {th }}$ century is a time when the West increaed its missionary work against Muslims with the Crusades. With this regard, missionaries who were proficient in Arabic were sent to the Islamic world and the excellent knowledge of Islam was considered necessary. William of Tripoli (d. 1277) is one of the figures who have lived in the East in the 13th century and have written about Islam and the Prophet. In this article, the reviews of William of Tropol, about the Prophet and the Quran are discussed within the scope of his two works, Notitia de Machometo (Knowledge of Muhammad) and De statu Sarracenorum (The State of Muslims), which are written in Latin and about Islam and the Prophet. The aim is to reveal the view on the Quran and the Prophet, based on the works of someone who lived in the 13th century in an environment close to the Muslims in the East and its impact on the formation of the image of Prophets in the West. William of Tripoli has several different thoughts that have not be seen in other authors. He has simple mistakes and conflicting views about the Quran or the Prophet. Some of Williams' claims were not repeated in Western sources.
\end{abstract}

Keywords: Hadith, Muhammad, Orientalism, William of Tripoli, The Qur'an. 


\section{Giriş}

Haçlı seferlerinin devam ettiği sırada Avrupa'da İslâm'a karşı savaşla değil, misyonerlikle mücadele edilmesini savunanların sayısı zamanla artmış ve 13 . asırda sistemli misyonerlik faaliyetleri başlamıştır. Bilhassa Fransisken ve Dominiken tarikatları Arapça bilen misyonerler yetiştirmişler ve bu kişileri İslâm dünyasına göndermişlerdir.' Ayrıca bazı Avrupalılar, Antakya Prensliği, Trablus Kontluğu ve Kudüs Krallığı gibi 12. ve 13. asırda Haçlılar tarafından Doğu'da kurulan HaçIı devletlerine yerleşmişlerdir. Avrupa'nın İslâm'ı tanımasında Haçlı seferleri ve William of Tripoli ve Ricoldus de Monte Crucis gibi uzun süre Doğu'da yaşamış bazı yazarların İslâm'a dair yazdıkları eserler, Avrupa'da yeni bir İslâm imajının oluşmasında etkili olmuştur. Bunlardan birisi de aslen Avrupalı bir aileye mensup olan ve bugün Lübnan sınırları içinde bulunan Trablusşam'a nispet edilen William of Tripoli'dir. William, İslâm, Kur'an, Hz. Peygamber ve Müslümanlar hakkında 1271 ve 1273 yıllarında Notitia de Machometo $^{2}$ ve De statu Sarracenorum ${ }^{3}$ adlı iki eser kaleme almıştır. ${ }^{4}$ Aynı zamanda bir misyoner ve diplomat olan yazar, söz konusu eserleriyle Batı'da oluşan Hz. Peygamber imajında etkili olmuştur.

William of Tripoli, her iki eserinde Hz. Peygamber'in hayatı ve Kur'an hakkındaki görüşleri müstakil bir araştırmayı gerektirecek genişliktedir. Onun bilhassa Resûlullah’ın risâlet öncesi hayatı bağlamında Bahîra kıssası hakkındaki iddiaları başka eserlerde pek bulunmayan özellikler taşımaktadır. Onun Kur'an'ın oluşumuna dair iddiaları da bazı Doğu ve Batı Hıristiyan kaynaklarına göre bir kısım farklılıklar göstermektedir. Bu sebeple William'ın Hz. Peygamber ve Kur'an hakkındaki iddialarının müstakil bir araştırma konusu yapılması uygun görülmüştür.

1 Bu hususta geniş bilgi için bkz. Sabri Çap, Goldziher Öncesi Oryantalizm ve Hadis, (Ankara: İlâhiyât, 2019), 138-140. Fransisken ve Dominiken tarikatları, 13. asrın başında kurulan ve dünyadan el-etek çekerek zühd hayatı yaşamayı ve Hıristiyanlığı tebliğ etmeyi hedefleyen mistik Katolik tarikatlardır. Bu tarikatlar hakkında geniş bilgi için bkz. Salihe Esen, "Dominiken Tarikatı ve Katolik Kilisesi'ndeki Yeri”, (Doktora Tezi, Ankara Üniversitesi, 2015), 69-146; Abdülkadir Kurt, “Hristiyanlık Tarihinde Fransisken Tarikatı”, (Yüksek Lisans Tezi, Necmettin Erbakan Üniversitesi, 2012), 64-80.

Eserin tam adı Notitia de Machometo et de libro legis qui dicitur Alcoran et de continentia eius et quid dicat de fide Domini nostri lesu Christi (Muhammed, Onun Kur'an denilen Şeriat Kitabı, Kur'an'ın Muhtevası ve Hz. Îsâ ve Dini Hakkında Söyledikleri) şeklindedir.

3 Eserin tam adı De statu Sarracenorum et de Mahomete pseudopropheta eorum et de ipsa gente et eorum lege (Müslümanların Durumu, Onların Sahte (!) Peygamberi Muhammed, Müslümanlar ve Dinleri Hakkında)'dır.

4 William of Tripoli'nin hayatı, eserleri, İslâm ve Müslümanlar hakkındaki bazı görüşleri için bkz. Sabri Çap, "Misyoner ve Oryantalist William of Tripoli'nin İslâm ve Hz. Peygamber Hakkındaki İki Eserinin Değerlendirilmesi". Dokuz Eylül Üniversitesi Illahiyat Fakültesi Dergisi, 52 (2020). 


\section{William of Tripoli'nin Hz. Peygamber Hakkındaki Görüşleri}

William'ın dikkate alınması gereken görüşlerinin başında onun diğer oryantalistlerden bazı farklılıklar gösteren Hz. Peygamber hakkındaki düşünceleri gelmektedir. William, her iki kitabında da Hz. Peygamber'e geniş yer vermiştir. O, Notitia de Machometo'nun hemen başında ithaftan sonra üç konuyu ele alacağını söylemektedir. Bunlardan birincisi "Muhammed kimdir ve onun halkı (ümmeti) olan Müslümanlar ve yanlış inançları (!) nereden geldi, nasıl hızlı ve güçlü yayıldı?"; ikincisi, "Muhammed'in Arapça el-Kur'an veya Furkan denilen Şeriat Kitabı nasıl ortaya çıktı, onu kim yazdı veya bir araya getirdi"; üçüncüsü, "Bu Kitap hangi inançları ihtiva ediyor ve Hıristiyanlık dininden hangi unsurları taşıyor" şeklindedir. ${ }^{5}$

Her iki kitapta tamamen Hz. Peygamber'e ayrılmış konu başlıkları olduğu gibi farklı meseleler münasebetiyle de Resûl-i Ekrem'den söz edilmiştir. Yazarın polemik veya oryantalistik eserlerin geneli dikkate alındığında $\mathrm{Hz}$. Peygamber için hakaret ifadelerinden kaçındığını söyleyebiliriz. Kanaatimizce bunun en büyük sebebi, aşağıda değinileceği üzere, onun Müslümanların kısa bir süre içinde Hıristiyan olacağına dair beklentisidir.

William, ilk kitabı Notitia de Machometo'da ilk üç konu başlığında Hz. Peygamber'den söz etmiştir. Bunlar;

1. "Hz. Muhammed'in' soyu ve ona tâbi olanlar",

2. "Hz. Muhammed nasıl kabul gördü",

3. "Hz. Muhammed'in topluluğu nasıl büyümeye başladı" konularıdır.7 Yazar bunlardan ilk iki konuda Bahîra hâdisesini, sonuncu konuda ise İslâm'ın Hz. Peygamber'le başlayan yayılışını ve fetihleri ele almıştır. Bu kısımda ayrıca dört halife, Emevîler ve Abbasîler dönemine de değinmiştir.

Müellifin De statu Sarracenorum adlı ikinci kitabının ilk üç konusu diğer eseriyle aynı olup dördüncü olarak "Muhammed ne zaman öldü" şeklinde bir konu baş-

5 Wilhelm von Tripolis, Notitia de Machometo, Hrsg. Peter Engels, (Würzburg- Altenberge: Echter Verlag, Oros Verlag, 1992), 195. Yazar, De statu Sarracenorum'da ise yine kitabın hemen başında ithaftan sonra üç konuyu ele alacağını söylemektedir. William of Tripoli'nin iki eseri Peter Engels tarafından Almanca'ya çevrilmiş ve Latincesi ile birlikte yayımlanmıştır. Biz makalede Türkiye'de yaygınlığı sebebiyle şahsın isminin İngilizce telaffuzunu (William of Tripoli) kullanmayı uygun gördük. Ancak onun iki eserinin yayınında Almanca telaffuz (Wilhelm von Tripolis) esas alındığı için yazarın eserlerine referanslarda Wilhelm von Tripolis şeklindeki telaffuzuna bağlı kaldık.

7 Wilhelm von Tripolis, Notitia de Machometo, 195-209. 
lığına yer vermiştir. ${ }^{8}$ Biz, öncelikle daha geniş olan De statu Sarracenorum'daki anlatılanları esas alacağız.

\subsection{Hz. Peygamber ve Bahîra}

William, kendisinden önce ve sonra İslâm'a karşı reddiye veya polemik türü eser yazan şahısların yaptığı gibi Bahîra'ya geniş yer ayırmıştır. Onun her iki eserinde de Resûlullah (s.a.v.) hakkında verdiği bilgilerin büyük bir kısmını Bahîra kıssası oluşturmaktadır. Yazarın yukarıda belirtilen ilk üç konuda iddia ettiğine göre;

"Milâdî 601 yılında9, Hıristiyanlık Mısır'da iyice geliştiği bir zamanda, Arap çölünden, Mekke Araplarının tarafından gelen, Kızıldeniz'in önünden, Sîna Dağı'nın solundan geçip devam eden (Suriye'den Mısır'a giden) yol kenarında bulunan bir manastırda Hıristiyanlık inancına sahip Bahîra adında dindar münzevî bir derviş yaşıyordu. Bahîra'nın münzevî bir hayat sürdüğü bu manastıra, dinlenme tesisi gibi, gün boyunca Suriye, Arabistan ve Mısır'dan gelen Hıristiyan ve Sarazen birçok tüccar uğrardı. Bahîra'ya ilhamla, bu manastıra gelenler arasında büyük ve güçlü bir halktan birinin geleceği ve bu kişinin Hıristiyanlara çok büyük sıkıntılar yaşatacağı bildirildi. Bahîra bu yeni doğan kişiyi görmeyi arzu etti ve hergün onun manastıra gelmesini bekledi.

Nihayet uzun süredir beklenen gün geldi ve Arapların "kâfile" dedikleri bir kervanla bir grup tüccar mezkûr manastıra ulaştı. Tüccarlar münzevî keşiş tarafından manastıra davet edildi. Fakat beklenen kişi onların arasında yoktu. Daha sonra hizmetçiler ve develeri bekleyenler de geldiler ve yine ilâhî ilhamla aranan kişi bulundu. Bu şahıs genç, yetim, hastalıklı, fakir ve yoksul, Genesis/Yaratılış, 16'da hakkında 'O, vahşi/yabanî bir adam olacak, onun eli herkese, herkesin eli de ona karşı uzak duracak. Bütün kardeşlerine göre o kendi çadırını kuracak (Kardeşleriyle anlaşmazlık içinde olacak) (Yaratılış, 16:12)' denilen İsmail'in soyundan gelen bir Arap deve bekçisidir. Bunu okuyan, bu gaybî haberin Hz. Muhammed'le gerçekleşip gerçekleşmediğini farkedebilir. Zira görüldüğü üzere, İsmail'in çocukları arasında böyle yabanî ve güçlü hiç birine rastlamıyoruz. Burada söz konusu olan kişiden başka hiç biri çadırlarını herkese karşı açmıyor/kurmuyor.

9 Bu tarih Notitia de Machometo'da 600 olarak zikredilmiştir. Bkz. A.g.e., 197. Onun bu tarihi niçin vurguladığı anlaşılamamıştır. 


\section{Sabri ÇAP \\ 13. Asır Misyoner ve Oryantalistlerinden William of Tripoli'nin Hz. Peygamber ve Kur'an Hakkındaki Görüşlerinin Tahlil ve Tenkidi}

Müslümanlar, bu zamanı Tanrı́nın küçük kulu için gerçekleştirdiği ilk mucize olarak kabul ediyorlar. 'Müslümanların anlattıklarına göre' manastırın bahçesinin küçük kapısı, bu genç girmek istediğinde ilâhî bir işaret olarak genişlemiş ve bir yay gibi yukarıya doğru uzamış, kayser veya kral sarayının ana kapısının girişine benzemiştir.

Genç, sonunda rahip Bahîra tarafından kabul edilmiş ve sevimli bir evlat gibi muamele görmüş, yedirilmiş ve giydirilmiştir. Herkes onu kalbine gömmüş, onu münzevî rahibin evlatlığı olarak isimlendirmiştir. $\mathrm{O}$, putlara saygı göstermekten kaçınmak, tek ilâha saygı duymak ve bâkire Meryem'in oğlu Îsâ'ya tam bir teslimiyetle dua etmek hususunda eğitim-öğretime tâbi tutulmuştur. Manastır mensupları, bütün çabalarına rağmen bu genci sürekli manastırda tutmayı başaramadılar. Onlar, bu kişiden tekrar dönmesine dair söz alarak onu serbest bıraktılar.

Mezkûr genç aynı zamanda üvey babası olarak kabul ettiği zengin bir tüccara da bağlıydı. $O$, zamanla büyümüş, çalışmış, efendisinin kazancını artırmıştır. Bu arada sık sık manastırdaki hocasına da sadık kalmış ve onu arayıp sormuş, manastırla münasebetini devam ettirmiştir.

Nihayet genç Muhammed'in çabaları sonucu büyük bir refaha ulaşmış olan efendisi öldü. Onun dul eşi, gencin güzelliğini ve çalışkanlığını görünce onu eş olarak aldı. Böylece hizmetçi efendiye dönüştü, zengin oldu, malı, ailesi ve bağlıları çoğaldı. Şairin dediği gibi: 'Çok malın olup zengin olursan, çok arkadaşın olur. Hava kararır/bulutlanırsa tekrar yapayalnız kalırsın.'

Daha sonra ona hediyeler sunulmuş, itaat sözü verilmiş, arkadaşları çoğalmış ve pekçok bağlıları olmuştur. Bunların en başta geleni, kan akrabası olan kuzeni Ali'dir ve o, Hz. Muhammed'in Fâtıma adındaki kızıyla evlenmiştir. Böylece bütün halk ona saygı duymaya başlamış, onu başkan olarak isimlendirmiş, efendi, lider ve hükümdar gibi ona saygı duymuşlardır. ${ }^{10}$ O, arkadaşlarından on kişiyi seçmiş olup bunlardan birincisi Ebû Bekir'dir. ${ }^{11}$ davet ettiği, Hıristiyanların Hz. Îsâ'yı sevmelerini ve ona saygı duymalarını, Yahudilerin de kendi Tanrı'larına yönelmelerini, hepsinin onu Allah'ın peygamberi olarak kabul etmelerini istediği herkesin "Allah'tan başka ilah yoktur ve Muhammed onun elçisidir" sözünü kabul etmelerini istediği ilave edilmektedir. Bkz. Wilhelm von Tripolis, Notitia de Machometo, 201.

11 William, burada diğerlerinin ismini zikretmemiştir. Fakat Notitia de Machometo'da onun bağIılarının on kişi olduğu, bunlar arasında yeğeni Ali, Ebû Bekir, Hasan, Hüseyin, Osman ve diğerlerinin olduğu, önce on kişi olan bu grubun daha sonra yirmi, sonra kırk, sonra devasâ bir topluluk olduğu ve bunların onu Allah'ın elçisi ve peygamberi kabul ettikleri belirtilmektedir. Wilhelm von Tripolis, Notitia de Machometo, 199. 
Zamanla Muhammed (s.a.v.) büyüdükçe büyümüş, ona tâbi olanların sayısı ve gücü de artmıştır. Yeryüzünde bulunan valiler, hükümdarlar, krallar ve milletler ondan korkmaya başlamışlardır. Bu arada o sık sık hocası Bahîra'yı ziyaret etmiş, onu arayıp sormuş ve uzun süre onun yanında kalmaya devam etmiştir. Fakat bundan arkadaşları üzüntü duymaya başlamışlardır. Hz. Muhammed (s.a.v.) onu severek dinlemiş ve onun için çok şeyler yapmıştır. Bu sebeple arkadaşları Bahîra'yı öldürme planı yapmışlar fakat krallarından korkmuşlardır.

Arkadaşları, münzevî rahibin bir gece kralları Hz. Muhammed'i, uzun süre tutarak sohbet ettiklerini gördüler ve buna çok kızdılar. Bu esnada krallarının sarhoş olduğunu fark ettiler ve geceleyin rahib Bahîra'yı Hz. Muhammed'in kılıcıyla öldürdüler. Böylece Hz. Muhammed'in aşırı sarhoşluğu sebebiyle hocasını ve destekçisini öldürdüğünü ileri sürerek suçu ona yüklemeyi hedeflediler. Sabah olduğunda Hz. Muhammed ayrılmak için izin istemek ve vedalaşmak maksadıyla hocasını aradı ve onun öldürüldüğünü gördü. Buna çok kızarak ve üzülerek kendinden geçti ve katilleri aramaya başladı. Fakat arkadaşları onu sarhoşken bu cinâyeti işlemekle suçladılar. $\mathrm{O}$, kendi kılıcının kanlar içinde olduğunu gördü ve arkadaşlarının sözüne inandı. Zira o, geçen gece sarhoş olduğunu çok iyi biliyordu, üstelik kendi kılıcı da kanlar içindeydi. Bunun üzerine sarhoşluğu ve ona sebep olan içkiyi yasakladı, içki taşıyanı, içeni, satanı ve satın alanı lânetledi. Bu sebeple dindar Müslümanlar (içki içmeyen bir topluluk olan) 'Recabiten-Rachabitarum' gibi içki içmezler. ${ }^{12}$

Hıristiyan Bahîra öldükten sonra, Hz. Muhammed'in taraftarları bütün askerî disiplinlerden bağımsız, caniler (!) gibi sağa-sola saldırmışlar, yağmacılar gibi her şeyi toplamışlar, öldürmüşler, tahrip etmişler, eyaletleri ve krallıkları felakete sürüklemişler ve bunlar Hz. Muhammed'in ölümüne kadar devam etmiştir."13

William, Notitia de Machometo'da ise Bahîra münasebetiyle içki yasağı efsanesine yer verdiği gibi, İslâm'da domuz etinin niçin haram olduğuna dair de ilginç bir gerekçe söylemektedir. Buna göre Müslümanlar domuz eti de yemezler, çünkü herhangi bir zamanda bir domuz Müslümanlar tarafından yapılan bir camiye girmiş ve burayı kirletmiştir. Wilhelm von Tripolis, Notitia de Machometo, 201. Engels, bu gerekçenin ne İslâm ne de Hıristiyan kaynaklarında bulunduğuna işaret etmektedir. Bkz. Peter Engels, Wilhelm von Tripolis Tractatus de statu Sarracenorum et de Mahomete pseudopropheta et eorum lege et fide; Notitia de Machometo De statu Sarracenorum. Kommentierte lateinisch-deutsche Textausgabe. Würzburg- Echter: Altenberge- Oros Verlag, 1992), 377, No: 16. Engels'in kendisine ait ifadelerin naklinde William'ın eserlerini ona nisbet ederek referans verdik. 
William'ın Bahîra efsanesi, Batı kaynaklarında pek gözükmeyen bazı unsurlar taşımaktadır. O, ilginç bir şekilde Hz. Peygamber'in Bahîra ile, hiç gitmediği halde Mısır'da Sînâ Dağı yakınında buluştuğunu ve bir müddet onun yanında kaldığını iddia etmektedir. Yine isim vermeksizin İslâm kaynaklarına nispet etmesine rağmen siyer kaynaklarında bulunmayan bazı hususları zikretmekte ve hâdiseyi Hıristiyan apokaliptikleriyle irtibatlandırmaktadır. Bahîra, öncelikle saygın bir Hıristiyan olarak tanıtılmaktadır.

William'ın sözünü ettiği Bahîra kıssasının bir benzeri Ermeni kaynaklarında da görülmektedir. Ermeni tarihçi Vardan Areveltsi (ö. 1271), Sergius isminde ve Arianizme bağlı râhibin Mısır çölünde Hz. Peygamber'le buluştuğunu, ona Eski Ahid ve (Apokrif kabul edilen İnciller'den) Çocukluk İncili'ni öğrettiğini ileri sürmektedir. Benzer bilgileri Ermeni Kiakos von Gantzac (ö. 1270) da zikretmekte olup her ikisinin Ermeni Thomas Ardzroum/Ardzruni'ye (ö. 910'dan sonra) dayanması muhtemeldir. ${ }^{14}$ Bahîra'nın Hz. Peygamber tarafından öldürüldüğü iddiası ve bu sebeple içki yasağının başlaması iddiası da Batı kaynaklarında bilinmemektedir. Çağdaş yazarlardan Engels'e göre bu, sözlü kaynaklara dayanmaktadır ve Doğu kökenlidir. Ona göre bu, 12. asırda Antakya civarında yazılmış Latince bir kaynağa dayanmakta olup burada Hz. Peygamber Nestûrî hocasının şöhretini kıskanmış, onu uykuda iken öldürmüş fakat bir öğrencisinin onu öldürdüğü iddia edilmiştir. Hz. Muhammed'in yardımıyla öğrencisi tespit edilmiş ve o da öldürülmüştür. Sonra Nesturius'un yerine Hz. Muhammed lider olarak seçilmiş ve içki yasağı da bunun üzerine başlamıştır. ${ }^{15}$ William'ın anlattığı Bahîra efsanesine benzer bir anlatım Mısır'da da bulunmaktadır. ${ }^{16}$

\footnotetext{
Deutschen Morgenländischen Gesellschaft. Supplement VIII: XXIV. Deutscher Orientalistentag (1988), 81, Dipnot 20. Wilhelm, Notitia de Machometo'da da Bahîra ile ilgili bilgilere yer vermekte, fakat her iki eser arasında bazı farklar bulunmaktadır. Burada Hz. Ali ve Ebû Bekir'den başka Hz. Hasan, Hüseyin ve Osman'dan da bahsetmektedir. Bkz. Wilhelm von Tripolis, Notitia de Machometo, 197-201. Engels, William'ın naklettiği Bahîra hâdisesinin benzerinin Ermeni kaynaklarında da bulunduğunu belirtmektedir. Bkz. a.g.e., 77. William, Bahîra'nın Mısır yakınlarında bir manastırda bulunduğu iddiası başta olmak üzere birçok gerçek dışı bilgiye yer vermiştir. Onun Bahîra hakkındaki değerlendirmeleri için bkz. Engels, a.g.e., 75-81. William'ın Hz. Peygamber hakkındaki görüşlerinin önemli bir kısmını Bahîra ile münasebetleri oluşturduğundan bu konudaki ifadelerini olduğu gibi aktarmayı uygun gördük.

14 Engels, Wilhelm von Tripolis, 77-78. Ermeni kaynaklarında Bahîra hakkında ayrıca bkz. Robert W. Thomson, "Armenian Variations on the Bahira Legend", Harvard Ukrainian Studies Vol. 3/4, Part 2. (1979-1980), 884-895.

15 Engels, Wilhelm von Tripolis, 79-80.

16 Bkz. Engels, Wilhelm von Tripolis, 80-81.
} 
Bahîra'nın öldürülmesine Batı'lı Ricoldo de Monte Croce (ö. 1320) ve Liber denudationis adlı eserin mechul yazarı da yer vermiştir. Yine alkol ve domuz eti yasağına dair anlatım, 9. asırda yazılmış olan Arapça ve Süryânîce bir metinde yer almaktadır. ${ }^{17}$ Pearson, içki ve domuz eti yasağına dair 9. asra ait Petrus'un Apokalipsinde gaybî haber olarak Mesih'in Petrus'un hocasını öldüreceğini, içki ve domuzu yasaklayacağını bildirdiğini nakleder. ${ }^{18}$ Yine şarapla ilgili anlatım Mısır'da ve Doğu Haçlı devletlerinde bilinmektedir. Ayrıca 11 veya 12. asra ait Liber Denudationis adlı anonim bir eserde ve Bizans nakillerinde de mevcuttur. ${ }^{19}$ Doğu ve Batı Hıristiyan kaynaklarında içkinin yasaklanması ve Bahîra ile irtibatlandırılmasının başka hangi kaynaklarda yer aldığı daha geniş bir araştırmayı gerektirmektedir.

Bahîra'nın öldürüldüğüne dair bilgiler 10. asırda yazılmış olan iki Ermeni kaynağına dayanmaktadır. Ermeni tarihçi Thomas Artsruni (ö. 904-908) ve Aghuank, tarihlerinde birbirinden farklı sebeplerle Bahîra'nın öldürülmesinden söz etmişlerdir. ${ }^{20}$ Farklı sebeplerle Bahîra'nın öldürülmesiyle sonuçlanan birçok efsane bulunmaktadır. William ise Bahîra'nın öldürülmesinden söz eden birkaç Latin'den biridir. ${ }^{21}$ Onun, Bahîra'nın öldürülmesiyle Hz. Peygamber'in onun rehberliğinden mahrum kaldığı ve bundan sonra ahlâkî değerlerden uzaklaştığı, saldırgan biri olduğu gibi bir kurgusu söz konusudur. ${ }^{22}$

William, Ricoldo ve mechul bir şahısla birlikte Bahîra adına yer veren üç Latin yazardan biridir. Başka eserlerde rahip Sergius'un putperest veya heretik biri ve $\mathrm{Hz}$. Peygamber'e Hıristiyanlığı öğrettiği iddia edilirken William bunlardan bahsetmemektedir. ${ }^{23}$ Diğer taraftan William’ın Bahîra efsanesiyle büyük ölçüde paralellik gösteren Arapça/Süryânîce bir metinden söz edilmektedir. Hz. Peygamber'in Bahîra ile karşılaşmasının Hıristiyanlık versiyonu olan bu metin, 9. yüzyıldan sonContext, (PhD diss., University of Tennessee, Knoxville (ABD): 2018), 84-85. Pearson, The Islamic World and the Latin East, 85.

19 Edeltraud Klueting, "Quis fuerit Machometus? Mohammed im lateinischen Mittelalter (11.-13. Jahrhundert)", Archiv für Kulturgeschichte 90 (2008), 303.

20 Bkz. Barbara Roggema, The Legend of Sergius Bahira Eastern Christian Apologetics and Apocalyptic in Response to Islam, (Leiden - Boston: Brill, 2009), 189. Ayrıca bkz. Cahit Külekçi, "Ermeni Kaynaklarında Siyer Anlatıları -Movses Dasxurants'i'nin Tarihi Örneği-" Akademik Siyer Dergisi, I/1 (2020): 148-149.

21 Bu hususta geniş bilgi için bkz. Roggema, The Legend of Sergius Bahira, 189-196.

22 Böyle bir değerlendirme için bkz. Roggema, The Legend of Sergius Bahira, 165.

23 Pearson, The Islamic World and the Latin East, 76. 
ra çoğalmaya başlamıştır. ${ }^{24}$ Bahîra kıssasının Hıristiyanlık açısından Arapça, Süryânîce ve Latince birden çok varyantları bulunmakta olup bunların hangisinin önce olduğuna dair farklı görüşler mevcuttur. ${ }^{25}$

William, Hz. Peygamber'in Doğu Hıristiyan kaynaklarında genel olarak farklı vasıflarla ve isimlerle tanıtılan Bahîra ile ilişkilerine yer vermekte ve bu anlatımla İslâm’ın kaynağını Hıristiyanlığa bağlamaktadır.

Görüldüğü üzere Bahîra hâdisesi erken dönemlerden itibaren İbn İshak, İbn Hişâm, İbn Sa'd gibi müelliflere ait siyer kaynaklarıyla birlikte İslâm dışı kaynaklarda da yer almıştır. İslâm tarihinde Hz. Peygamber'in risâletini önceden haber verenlerden birisi Bahîra'dır. İslâm dışı kaynaklarda birçok versiyonunu görmenin mümkün olduğu bu hâdise, Hz. Peygamber hakkındaki çağdaş eserlerde de yerini almaya devam etmektedir. Bilhassa erken dönem İslâm dışı kaynaklarda hâdisenin bütün versiyonlarının tespiti ve ilk defa hangi eser veya eserlerde nasıl yer aldığının ve hangi maksatla uydurulduğunun daha geniş araştırılması gerekmektedir. Fakat bu, bizim konumuzun sınırlarını aşmaktadır.

Son zamanlarda ülkemizde artış gösteren Hz. Peygamber'in risâlet öncesi hayatına dair araştırmalarda onun Suriye yolculuğuna ve Bahîra kıssasına geniş yer verildiği görülmektedir. Bu araştırmalarda hâdisenin sahih olmadığına dair görüşler öne çıkmaktadır. ${ }^{26}$ Müslüman yazarlar, Bahîra hâdisesini reddederken diğer bazı gerekçelerle birlikte daha çok müsteşriklerin İslâm'ın ve Kur'ân'ın kaynağı olarak Bahîra'yı göstermelerini vurgulamışlardır. Hâlbuki Bahîra hâdisesi İslâm kaynaklarının dışında Süryânî ve Ermeni kaynakları başta olmak üzere Doğu Hıristiyan kaynaklarında, Bizans ve Latin/Batı Hıristiyan kaynaklarında birbirinden farklı şekillerde yer almaktadır. Bunların bazılarında Bahîra yüceltilirken bir kıs-

Bkz. Pearson, The Islamic World and the Latin East, 78-80; Sidney H. Griffith, "Muhammad and the Monk Bahīrā: Reflections on a Syriac and Arabic Text from Early 'Abbāsid Times, Oriens Christianus 79 (1995): 146-174. Bahira hakkındaki literatürün teşekkülü, yazarları, Bahîra'ya nispet edilen isim ve özellikler ve $\mathrm{Hz}$. Peygamber'le münasebetleri hakkında ayrıca bkz. Krisztina Szilagyi, "Muhammad and the Monk: the Making of the Christian Bahira legend", Jerusalem Studies in Arabic and Islam 34 (2008): 169-207. djährigen Weissagung, (Stuttgart: Jan Thorbecke Verlag, 2000), 128-130.

26 Örnek olarak bkz. Mehmet Apaydın, Siyer Kronolojisi (İstanbul: Kuramer Yayınları, 2018), 236251; Emine Demil, “Hz. Peygamber'in Risâlet Öncesi Hayatına Dair Rivâyetler”, (Doktora Tezi, AÜSBE, 2016), 219-240; İsrafil Balcı, Peygamberlik Öncesi Hz. Muhammed, (Ankara: Ankara Okulu Yayınları, 2014), 240-249; Gülgün Uyar, "Hz. Muhammed'in Risalet Öncesi Hayatına Dair Bazı Rivayet Farklarının Tesbiti”, (Yüksek Lisans Tezi, MÜSBE, 1993), 49-56. 
mında ise aşağılanmaktadır. Bahîra hâdisesini bütün İslâm ve İslâm dışı kaynakların dikkate alınarak coğrafya ve tarihte nasıl değişikliklere uğradığının ve birbirinden etkilenip etkilenmediğinin ancak etraflıca araştırmayla ortaya çıkacağı anlaşılmaktadır. Türkçe'de bu hususta sınırlı araştırmaya karşılık ${ }^{27}$ Batı'da yapılan bir çok çalışma mevcuttur. ${ }^{28}$ İslâm ve İslâm dışı kaynakların Bahîra hâdisesinde birbirini etkileyip etkilemediği, etkinin hangi yönde olduğu, gerçeklik, yorum ve ilave unsurlarının bulunup bulunmadığı, Mekke veya Medine yakınlarındaki Hıristiyanlardan biri yerine Busra'daki bir râhibin seçilmesinin sebebi gibi hususlar ayrıntılı araştırmayı gerektirmektedir. Zira İslâmî ve İslâm dışı kaynaklarda birbirinden çok farklı “Bahîra”lar vardır. William ise âdeta İslâm ve Doğu-Batı Hıristiyan kaynaklarına dayanarak yeni bir Bahîra efsanesi oluşturmuştur.

27 Siyer ve İslâm tarihi araştırmalarında bölüm veya dolaylı olarak konuya yer veren çalışmaları bir tarafa bırakırsak; Ahmet Erçetin tarafından "Rivâyetler ve Farklı Yorumlar Işığında Rahip Bahîra Olayı" adıyla bir yüksek lisans tezi (SÜSBE, Konya 2008) hazırlanmıştır. İhsan Arslanıı "Vahiy Bağlamında Rahib Bahîrâ Olayı'nın Değerlendirilmesi", Recep Tayyip Erdoğan Üniversitesi Sosyal Bilimler Dergisi 8 (2018): 313-341 ve Halis Demir, Recep Tayyip Gedikli, Mikail Şeker'in “islam Tarihindeki Bir Vakanın Yorum Kritiği: Rahip Bahira Olayı", Ağrı İslâmi Illimler Dergisi, 2018 (2): 57-92 adlı makaleleri bulunmaktadır. Yine Ali Rıza Sağman'ın İslâm Tarihinde Rahip Bahîrâ Meselesi, (İstanbul: Ahmet Sait Yayınları, 1959) adlı kitabı ile Fatımatüz Zehra Kamacı'nın Richard James Horatio Gottheil'in konuyla ilgili eserinin Bir Hıristiyan Bahîrâ Efsanesi -Bir Tahrif Örneği (XI-XII. Yüzyıl) adıyla yapılan tercüme, yorum ve değerlendirmesi (İstanbul: İnkılab Yayınları, 2008) konuyla ilgili çalışmalar arasındadır.

28 Örnek olarak bkz. Aloys Sprenger, "Mohammad's Zusammenkunft mit dem Einsiedler Bahyrâ", Zeitschrift der Deutschen Morgenländischen Gesellschaft, 12 (1858), 238-249; Krisztina Szilágyi, "Muhammad and the Monk: the Making of the Christian Bahira Legend", Jerusalem Studies in Arabıc and Islam 34 (2008), 169-214; Richard Gottheil, "A Christian Bahira Legend", Zeitschrift für Assyriologie, 13 (1898), 189-210; 14 (1899-1900), 203-268; 15 (1901), 56-102; 17 (1903) 125-166; Barbara Roggema, "A Christian Reading of the Qur'an: The Legend of Sergius-Bahira and its Use of Qur'an and Sira", Syrian Christians under Islam the First Thousand Years, Ed. David Thomas, (Leiden: Brill, 2001), 57-73; a.mlf., The Legend of Sergius Bahira Eastern Christian Apologetics and Apocalyptic in Response to Islam, Leiden-Boston: Brill, 2009; a.mlf., "Salvaging the Saintly Sergius: Hagiographical Aspects of the Syriac Legend of Sergius Bahịirā", Entangled Hagiographies of the Religious Other, edit.: Alexandra Cuffel \& Nikolas Jaspert, Newcastle: Cambridge Scholars Publishing, 2019, 55-83; a.mlf., "The Legend of Sergius-Bahîrâ Some Remarks on its Origin in the East and its Traces in the West", East and West in the Crusader States Context-Contacts-Confrontations-II, Edit.: Krijna Nelly Ciggaar, Herman G. B. Teule, Acta of the Congress Held at Hernen Castle in Mai 1997, Leuven: Uitgeverij Peeters, 1999, 107-123; Sidney H. Griffith, "Muhammad and the Monk Bahīrā: Reflections on a Syriac and Arabic Text from Early 'Abbāsid Times, Oriens Christianus 79 (1995): 146-174; Abjar Bahkou, "The Monk Encounters the Prophet-The Story of the Encounter between Monk Bahīra and Muhammad as it is Recorded in the Syriac Manuscript of Mardin 259/2", Cultural and Religious Studies, 3/6 (Nov.-Dec. 2015): 349-357. 


\subsection{Hz. Peygamber'in Vefatı}

William'ın De statu Sarreconum'da "Muhammed Ne Zaman Öldü" adlı dördüncü konuda ise şu bilgiler yer almaktadır:

Hz. Muhammed'in ölümü hakkında, tâbileri (ümmeti) onun, doğduğu Arap şehri olan Mekke'de öldüğünü söylüyorlar. Chronica Orientalium'da yer aldığı üzere onun, kayser Herakleios'un Suriye'de bulunduğu 11. yılda öldüğü kesindir. Bu senede Roma'da Honorius (ö. 638) papalığa seçildi ve Modestus (ö. 630) Kudüs'te patrik idi. Muhammed, kayserin Suriye'ye geldiği ilk yıldan itibaren 11 yıl süreyle refah ve şöhret içinde yaşadı. O, ölümünden sonra geride Fâtıma adında kızından başka vâris bırakmadı. Onun da kırk gün sonra babasının ardından vefat ettiği söylenir. ${ }^{29}$

William devamla Hz. Ebû Bekir'in halife olduğunu ve onun zamanında fethedilen yerlerin genişliğini açıklamaktadır. $\mathrm{O}, \mathrm{Hz}$. Peygamber'in ölümüne dair aktardıkIarını Eutychius'un Chronica Orientalium adlı eserine nispet etmesine rağmen buradaki bilgilerin farklı olduğu belirtilmektedir. ${ }^{30}$

Notitia de Machometo'da ise William, Hz. Peygamber'in vefatı hakkında daha farkIı bir bilgi vermektedir. İslâm yayılırken, İskenderiye'de bulunan yerlilerle Bizanslı tüccarlar arasında tartışma çıkmış, Bizanslılara karşı Mısırlılar ücret karşııı̆ında $\mathrm{Hz}$. Peygamber'in ordusundan yardım istemişlerdir. Hz. Muhammed onların bu talebini onaylamış, fakat İskenderiye'ye ulaşamadan 63 yaşında vefat etmiştir. ${ }^{31}$

Yazar, Müslümanlara isnad ederek Hz. Peygamber'in, doğduğu şehir olan Mekke'de vefat ettiğini bildirmektedir. Ortaçağ'da Batı'da Hz. Peygamber'in kabrinin Mekke'de olduğu bilgisi oldukça yaygındır. ${ }^{32}$ Diğer bazı konularda olduğu gibi

31 Wilhelm von Tripolis, Notitia de Machometo, 203. Guibert de Nogent'in 1109'da yazdığı ve en erken Latince eserlerden kabul edilen Gesta Dei per Francos adlı eserinde Hz. Peygamber'in İskenderiye yakınlarında bilinmeyen bir yerde öldüğüne dair verdiği bilgi için bkz. Michelina Di Cesare, "On Relics and Mausoleums: The Death of the Prophet Muhammad between History and Legend in the Mediterranean Context", Propaganda and (Un)covered Identities in Treatises and Sermons: Christians, Jews, and Muslims in the Premodern Mediterranean, Edit.: Cándida Ferrero Hernández \& Linda G. Jones (Bellaterra: Universitat Autònoma de Barcelona Servei de Publicacions, 2020), 60, 63.

32 Bu hususta geniş bilgi için bkz. Cesare, "On Relics and Mausoleums: The Death of the Prophet Muhammad between History and Legend in the Mediterranean Context", 57-70; Rotter Ekkehart, "Mohammed in der Stadt, Die Erkenntnis um die Stadt Medina und das dortige Prophetengrab im mittelalterlichen Europa", Zeitschrift für historische Forschung, 36 (2009): 183-233. 
onun bu hususta Batı'daki genel kabulün etkisinde kaldığını görmekteyiz. William'a göre Resûlullah'ın vefatından sonra onun on arkadaşından birincisi olan Ebû Bekir halife olmuş ve onun zamanında Müslümanların hâkimiyeti genişlemiştir. ${ }^{33}$ Onun aşere-i mübeşşere telakkisine imada bulunduğu anlaşılmaktadır. William, Müslümanlardan nakilde bulunmakta, fakat bu hususta bir şahıs ismi ve herhangi bir eser adı zikretmemektedir. Bu bilgilerin yazılı veya sözlü kaynağa dayandığı hakkında bir şey söylemek mümkün değildir.

William, Hz. Peygamber'in vefatı hakkında açıkça yanlış olan iki farklı bilgi nakletmektedir. Onun bir nakline göre " $\mathrm{Hz}$. Muhammed 63 yaşında İskenderiye önlerinde" vefat etmiştir. ${ }^{34}$ Diğerine göre ise "ona tabi olanlar, onun doğduğu şehir olan Mekke'de öldüğünü" söylemişlerdir. ${ }^{35}$ Onun Müslümanlara nispet ederek aktardığı bilginin yanlış olması kasıt veya dikkatsizlik sonucu olabilir.

\subsection{Mısır'ın Hz. Peygamber Tarafından Fethedildiği Idddiası}

William'ın Mısır'ın Müslümanlar tarafından fethedildiğine dair nakilleri de $\mathrm{Hz}$. Peygamber'le ilişkilidir. O, Notitia de Machometo'da, Bahîra öldükten sonra Hz. Muhammed'e bağıı olanların, Moğolların yaptığı gibi, şehirlere ve kalelere saldırdıklarını, Müslüman olmayanları öldürdüklerini, kendilerine katılanları ise koruduklarını, Herakleios'un (ö. 641) İran kisrası Hüsrev'i (ö. 628) yendikten sonra Konstantiniyye'ye çekilmiş olduğundan, Bizans'a bağlı eyaletlere Bizans ordularının koruyamadığı bir zamanda saldırdıklarını belirtir ve şöyle devam eder:

“Bu arada İskenderiye'de oturanlar arasında bir tartışma çıktı. Bir tarafta
yerli Mıırlılar, diğer tarafta ise Rum asıllı tüccarlar vardı. Mısırlılar Rumların
kendilerinden üstün olduklarını görünce o zamanda güçlü olan Hz. Mu-
hammed'in ordusundan büyük bir ücret karşılı̆ında destek istediler. Hz.
Muhammed onların isteğini onayladı fakat kendisi İskenderiye'ye ulaşa-
madan 63 yaşında vefat etti. Buna rağmen ordu Hz. Muhammed'in verdiği
sözü yerine getirdi. Mısırlılara yardım edildi, fakat onlar Rumların sürülme-
si karşıı̆ı̆ında söz verdikleri ücreti ödemek istemediler. Fakat galip gelen
Müslümanlar 'söz verdiğiniz ücret sizde kalsın. Biz zaferden memnunuz,
fetihle alınan ganimeti paylaşacağız. Güçlü ordumuzla fethettiğimiz şehir

Wilhelm von Tripolis, De statu Sarracenorum, 277-279. Bu değerlendirme, Üsâme ordusu hakkında olabilir. 
bizimdir. Önceleri siz yerli, biz misafirdik. Hz. Muhammed'in kabiliyet ve lütfuyla artık biz efendi olduk, sizler ise kölelersiniz' dediler. Böylece onlar bu şehrin heretik patriği Dioskoros (ö. ?) zamanından beri aralıksız olarak İskenderiye'ye sahipler." ${ }^{\prime 36}$

Bilindiği gibi Mısır, Hz. Peygamber zamanında değil, Hz. Ömer zamanında fethedilmiştir. William'ın sözünü ettiği hususun Hz. Peygamber'in Mukavkıs'a yazdığı mektupla irtibatlı olması ihtimal dâhilindedir. William ilginç bir şekilde hem Bahîra ile görüşmeyi hem de Hz. Peygamber'in vefatını Mısır'la irtibatlandırmıştır.

\subsection{Kâinatın Hz. Peygamber İçin Yaratıldığına Dair Tartışmalar}

William'ın dile getirdiği diğer bir husus ise kâinatın Hz. Peygamber için yaratıldığı, Hz. Peygamber yaratılmasaydı, kâinatın yaratılmayacağına dair tartışmalardır. Yazar, Cuma namazı hakkında geniş bilgi verirken namazın sonunda hutbede "Ravi"nin (kâdî) Allah'a hamd ettikten sonra peygamberi övüp medhettiğini, sonra Hıristiyanlara hakaret ettiğini, İncil'i tahrif ettikleri ve Hz. Muhammed'in düşmanı oldukları için onları azarladığını söylemektedir. Hatibin, hutbesini ve İslâm'ı methetmeyi, eğer Allah gelecekte böyle büyük bir peygamber göndermeyi takdir etmemiş olsaydı gökleri, yeri ve bütün insanları yaratmayacağını, bu peygamberin adının cennetin kapısının üzerinde yazılı olduğunu ve onun Allah'ın peygamberi olduğunu kabul etmeyen hiçbir kimsenin bu kapıdan giremeyeceğini bildirerek tamamladığını söylemektedir. ${ }^{37}$

\subsection{Hz. Peygamber'in Risâletini Reddetmesi}

William, Hz. Peygamber'in risâletini doğal olarak reddetmekte ve farklı konular münasebetiyle bunu mükerreren dile getirmektedir. Onun risâletle ilgili ileri sürdüğü polemik türü argümanları ise dört İlâhî kitabın bildirdiğine göre Hz. İbrahim'den itibaren gönderilen bütün peygamberlerin İsrailoğullarından olduğu ve Hz. Muhammed'in Yahudi olmadığı ve Hz. Îsâ'nın onun peygamberliğini bildirmediğidir. Onun Hz. Peygamber hakkındaki polemiklerinin Batı ve Doğu Hıristi-

37 Wilhelm von Tripolis, Notitia de Machometo, 261. İslâm kaynaklarında böyle bilgiler bulunmakla birlikte bu ifadeler hutbede dile getirilmemektedir. Fakat erken dönemlerde gayr-i Müslimlerle birlikte yaşanan beldelerde istisnai ve bireysel olarak böyle bir uygulama olabilir. Zira yazar, Haçlı seferlerinin devam ettiği bir ortamdan söz etmektedir. 
yan kaynaklarıyla örtüştüğünü söyleyebiliriz. William, Resûlullah'ın risâletini red gerekçesi olarak peygamberlerden hiç birinin şehvet düşkünü, içki bağımlısı, katil, yağmacı, bütün insanları kendi peygamberliğini kabul etmeye zorlayan veya kılıcıyla öldüren Hz. Muhammed gibi despot/zalim (!) olmadığını iddia etmektedir. O, bütün Müslümanların da Hz. Muhammed gibi, insanları korkutarak İslâm’ı kabul etmeye zorladıklarını ve İslâm'ı kılıçla yaydıklarını iddia etmekte ve "Ey Müslüman! Nasıl peygamberin Muhammed'in Allah tarafından gönderildiğini ve onun dininin Allah'tan olduğunu iddia edersin?" diyerek polemik yapmaktadır. ${ }^{38}$

Yine Hz. Peygamber'in okuma-yazma bilmediği halde nasıl bir kitaba sahip olabileceğini, Kur'an’ı Hz. Osman'ın Peygamber'in ölümünden 11 yıl sonra, öldürülme korkusuyla Müslüman olan Yahudi ve Hıristiyanların yardımıyla bir araya getirdiğini bütün Müslümanların kabul ettiğini, bu sebeple Kur'an'ın Hz. Peygamber'e değil Osman'a ait olduğunu, Kur'an'da Hz. Peygamber'in isminin sadece bir yerde geçtiğini ve burada da onun övülmediğini, Kur'an'ın Hz. Meryem'i Hârûn'un kardeşi olarak zikrettiğini ve Hz. Peygamber'in gelecekten haber vermediğini bir Müslümanla polemik üslûbuyla dile getirmektedir. ${ }^{39}$ William'ın Resûlullah'ın peygamber olmadığına delil olarak ileri sürdüğü diğer bir husus da yine birçok polemik eserinde görüldüğü üzere onun istikbalden haber veren gaybî haberlerinin olmadığıdır. ${ }^{40}$ Ancak aşağıda görüleceği üzere o, Hz. Peygamber'e ait olduğunu belirttiği bazı gaybî haberleri delil olarak kullanmakta ve bunları doğru kabul etmektedir. Böylece o kendisiyle çelişmektedir. William'ın Hz. Peygamber'in risaletini reddederken diğer reddiye ve apolojik literatürdeki argümanlardan farklı bir şey ileri sürmediğini söyleyebiliriz.

William, diğer taraftan Memlük sultanlarından I. Baybars'ın (1260-1277) Peygamber sevgisini ve Hz. Peygamber'e bağlıı̆̆ını takdir etmektedir. Baybars hakkında övücü sözler söyleyen William, onun Hz. Muhammed'e çok saygılı olduğunu vurgulamaktadır. Ona göre Baybars, sadece bir defa Hz. Peygamber'in kabrini ziyaret etmiş olmaktan memnun değildi. Bu sebeple ikinci defa yola çıktı ve bu seferinden, "De statu Sarracenorum'un yazıldığı sene olan 1273" yılında dönmek istiyordu. $^{41}$ hammed'in asla bir harfi bile tanımadığını bilirler. O, nasıl dinini ihtiva eden bir kitap yazmış olabilir?" diyerek polemiği sürdürmektedir.

39 Bkz. Wilhelm von Tripolis, Notitia de Machometo, 239-249; De statu Sarracenorum, 341.

40 Wilhelm von Tripolis, Notitia de Machometo, 249.

41 Wilhelm von Tripolis, De Statu Sarrazenorum, 329. 


\subsection{Hz. Peygamber'in Hadislerini Delil Olarak Kullanması}

Doğu'da ve Batı'da bilhassa Ortaçağ'da İslâm ve Hz. Peygamber aleyhtarı yazılan eserlerde Kur'an'dan alıntılar yapılırken hadisler nadir olarak kullanılmaktadır. ${ }^{42}$ William'ın erken sayılabilecek bir dönemde hadislere yer vermesinin dikkat çekici olduğunu belirtmeliyiz. ${ }^{43} \mathrm{O}$, genel olarak bir Müslümana hitaben yürüttüğü polemikte "Senin inancına göre Îsâ bütün peygamberlerden üstün ve gökte hayatta olup ölmemişse ve Muhammed ölmüş ve sen onun ruhunun nerede olduğunu bilmiyorsan, o hayatta iken kendi ümmetinin yetmiş gruba ayrılacağını, bunlardan sadece bir grubun kurtuluşa ereceğini ve bu grubu kimsenin tanımadığını söylemişse, sen böyle bilgisiz, hayırdan çok bozgunculuğu öğreten birinin yolundan gitmekten korkmuyor musun? Niçin hayatta olan ve kendisine tâbi olanlara hayat vaadeden Îsâ'ya koşmuyorsun?" diyerek 73 fırka hadisine ${ }^{44}$ işarette bulunmakta ve bu rivayeti kendine göre yorumlamaktadır. ${ }^{45}$ Erken dönemden itibaren William’la birlikte diğer bazı gayr-i müslim yazarların hadisleri yorumlamaları müstakil bir çalışma hacmine sahiptir.

William, Müslümanların hükümdarlarından ve bu münasebetle Bağdat, Mısır ve Marakeş'te bulunan üç halifeden söz ederken Bağdat'taki halifenin Peygamber'in mirasına sahip olduğunu söyledikten sonra şöyle der: "Bu hükümdarı- her mezhebin âlimleri böyle diyorlar ve bu, Müslümanların umumî bir inancıdır- 42 vâris takip edecek ve daha sonra Muhammed'in soyu ve Ehl-i beyt'i zulüm ve şiddetle sona erecek. Artık bu şehirde başka bir halife gelmeyecek. Müslümanlar bunu Peygamber'in bir gayb haberi kabul ediyorlar. Bu sayının tamamlanmasından sonra diğer bir halife, yani 43. kişi gelince, Müslümanlar Hz. Muhammed'in gaybî haberinin gerçek olmadığına inandılar, fakat daha sonra Bağdat, 1253'de Moğollar tarafından alınıp tahrip edilince bunu hakikat/doğru kabul ettiler." ${ }^{\prime 46}$

William, Notitia de Machometo'da ise üç gaybî haber aktarır. O, Müslümanların dinlerinde Rumların veya Latinlerin onlar tarafından mağlub edileceğini, onların mağlup ve yok edilmeleri gerektiğinin yazılı olduğunu ve Müslümanlardan buna itiraz eden hiçbir kimsenin olmadığını belirtir. ${ }^{47}$

Oryantalistik eserlerde hadislere yer verilmesi hakkında geniş bilgi için bkz. Sabri Çap, Goldziher Öncesi Oryantalizm ve Hadis, İlahiyat, Ankara: 2019. William of Tripoli'nin hadis nakli ve yorumları için ayrıca bkz. Çap, Goldziher Öncesi Oryantalizm ve Hadis, 150-154.

44 Ebû Dâvud, "Sünne", 1; Tirmizî, “Imân", 18; Ibn Mâce, "Fiten", 17.

45 Wilhelm von Tripolis, Notitia de Machometo, 249.

46 Wilhelm von Tripolis, Notitia de Machometo, 251. 
William, De Statu Sarracenorum adlı eserinde "Müslümanların (Sarazenlerin) papaları olarak gördükleri halifenin hâkimiyeti ve kaç halife olacağına dair" adlı konu başlığında Hz. Muhammed'den sonra Arapların halife diye isimlendirilen ve $\mathrm{Hz}$. Muhammed'in halefi olan 42 idarecinin bulunduğunu, bunun bir gaybî haber olduğunu, "yazarların ve Müslüman âlimlerin" Müslümanların hâkimiyetlerinin ve devletlerinin 42 halifeden sonra tahrip olup yok olacağını haber verdiğini söylemektedir. Yine onun iddiasına göre 43. halife işbaşına geçince birçok Müslüman, peygamberlerinin yalan söylediğine (!) inanmıştır. Ancak, Moğol hükümdarı Hülâgû'nun (ö. 663/1265) Bağdat'ı ele geçirip Hz. Muhammed'in Ehl-i beyt'inden olan 43. halifeyi bütün çocukları ve akrabalarılla birlikte öldürünce onun neslinin hâkimiyetinin sona erdiğini kabul etmişlerdir. Çünkü Peygamber'in soyundan veya kabilesinden geride halife olarak isimlendirebilecekleri kimse kalmamıştı. Böylece Hz. Muhammed'in soyunun devleti ve hâkimiyeti, Araplardan Türklere geçmiştir. ${ }^{48}$

William'ın hadislere yer verdiği en geniş bölüm ise 23. konu olan "Müslümanların Sonu Hakkında"dır. O, Müslümanların kendi sonlarına dair kesin bilgi ve sağlam inanca sahip olduklarını iddia ettikten sonra şöyle der:

Muhammed şöyle demiştir: Müslümanlar muhacir olarak başladılar ve daha önce oldukları gibi tekrar muhacir olacaklar. Müslümanların âlimleri nakledilen bu sözü şöyle yorumluyorlar: Müslümanlar üç gruba ayrılmak suretiyle İslâm son bulacak. Bir grup kılıç altında ölecek, bir grup çöle kaçacak ve orada yok olup gidecek ve bir grup ise Hıristiyanlığa geçecek. Onların diğer bir inanç kaidesi ise şöyledir: Sarazenlerin dini Muhammed'in kılıcıyla yükseldi ve Allah'tan gelen bir kılıçla yıkılacaktır. Kısaca ifade edilecek olursa; İslâm kılıçla başladı, tekrar kılıçla sona erecektir. ${ }^{49}$

Diğer bir inanç ise şöyledir: Yahudiler kendi zaman ve mevkilerine sahiptiler ve yok oldular. Aynen böyle, Sarazenlerin varlığı ve hâkimiyeti de yok olacaktır. Fakat Hıristiyanların inancı ve varlığı Hz. Îsâ şu an hayatta olarak beklediği gökten tekrar gelinceye kadar ve her şeyi dosdoğru yapıncaya kadar ve deccali öldürünceye kadar devam edecek. nin kalmadığını belirttiği diğer bir yerde de söz konusu gayb haberinin doğruluğunu belirtmektedir. bkz. a.g.e., 303-305. 


\begin{abstract}
Yine kimsenin yalanlamadığı diğer bir inanç daha vardır ve bu metin şöyle der: Eğer Hz. Muhammed'in Ehl-i beyt'i ve Bağdat'ta halifenin sarayında sürekli saygı gösterilen soyu sona ererse, Müslümanların dini ve ümmeti de son bulur. Fakat Hülâgû adındaki Moğol hükümdarı tarafından Bağdat ele geçirilip halife öldürülünce bu hane tamamen yok oldu. Bu, daha önce söylendiği gibi $1253^{50}$ yılında gerçekleşti. Bu yüzden Müslümanlar onların sonu çok yakındır diyorlar.

Yine diğer bir inanç daha vardır: Hebbas (Abbas) adıyla Bağdat'ta ilk halife olanın soyundan, sadece 42 halife gelecektir. Bu sayı, Hülâgû'nun 43. halifeyi öldürmesinden önce tamamlandı.

Diğer bir belge ise daha öncekileri de tasdik eden şu (bilgidir): Müslümanların devleti ve hükümranlığı Arapların elinden alınacak ve Türklerin eline geçecektir. Müslümanların artık bir zamanlar Bizans Hıristiyanlarından aldıkları ülkede Araplardan gerçek bir sultanları yoktur. Onların, Araplardan ileride geleceğini bekleyebilecekleri bir halifeleri de yok. Zira Muhammed halifenin hâkimiyeti sona erer ermez, Arapların hükümranlığının da sona ereceğini söylemişti. ${ }^{51}$
\end{abstract}

Görüldüğü üzere William fiten ve kıyamet alametleriyle ilgili bazı rivayetleri nakletmiştir. $\mathrm{O}$, bu rivayetler için kaynak olarak bir şahıs veya eser belirtmemiştir. William'ın aynı zamanda İslâmî rivayetleri yorumladığını görüyoruz. Bu tarz yorumlar diğer bazı reddiye ve polemik türü eserlerde de vardır. Bu yorumlar İslâm âlimlerine, sözlü kaynaklara ve Müslümanlarla yaptıkları teolojik tartışmalara dayanabilir. William, fiten hadislerine ve nüzûl-i Îsâ rivayetlerine atıfta bulunmaktadır. Öyle anlaşılıyor ki, bu tarz rivayetler teolojik tartışmalarda söz konusu edilmekte, bunlara Hıristiyanlık apokaliptik nakil ve yorumları da eklenmektedir.

\title{
1.7. Hz. Peygamber'e Hakaret Ifadelerinin Azlığı
}

Ortaçağ Latin polemik ve apolojik edebiyatında Hz. Muhammed için sahte bir peygamber, deccal'ın öncüsü, deccal, putperest veya heretik gibi çeşitli ifadeler kullanılırken ${ }^{52}$ William'ın, kendi döneminde kullanılan hakaret ifadelerinden kaçındığını görmekteyiz. Kendisinden öncekilere, çağdaşlarına ve sonrakilere vom 8. Jahrhundert bis zur Gegenwart, (Neukirchen: Neukirchener Verlag, 2006), 60-61.

51 Wilhelm von Tripolis, De statu Sarrazenorum, 331-335. Yazar bunlar arasında “Kur'an'da şöyle yazılıdır" diyerek Rûm sûresinin ilk âyetlerini de söz konusu etmektedir.

52 Maciej (Łódź)Dawczyk, "The Image of Muhammad in Riccoldo da Monte di Croce's Contra legem Sarracenorum", Studia Ceranea 9 (2019): 394. 
nispetle az sayıda hakaret ifadesi kullanan yazarın, Hz. Peygamber hakkında kullandığı tahkir ifadelerinin başında, birkaç defa tekrarladığı "sahte peygamber" ifadesi gelmektedir. ${ }^{53}$ William, Hz. Muhammed hakkında bir miktar doğru bilgi nakletmekteyse de genel olarak o da Hz. Peygamber'i tarihî kimliğinden oldukça uzak bir şekilde takdim etmektedir.

\section{William of Tripoli'nin Kur'an Hakkındaki Görüşleri}

William'ın her iki eserinin önemli bir kısmı Kur'an hakkında bilgi vermeye ve Kur'an'dan yapılan nakillere ayrılmıştır. O, Notitia de Machometo'nun hemen başında eserin muhtevasını zikrettikten sonra Müslümanların şeriat kitabının (Kur'ân) nasıl oluştuğunu ele alacağını belirtir ve bu kitaba Arapça "Alcoran-el-Kur'ân" veya "Forcan (Furkân)" denildiğini belirtir. ${ }^{54}$ William, 15 konu başlığından ibaret olan Notitia de Machometo adlı eserinin 5. "Muhammed'in Kanunu/Kitabı nasıl ve nereden geldi", 6. "Beş Kitap Allah'ın diniyle gökten geldi, Müslümanlar kendi kitaplarının kutsal kitaplar arasında olduğunu iddia ediyorlar", 7. "Kur'an'ın girişi nasıldır", 9 ve 10. "Sarazenlerin kitabının Hz. Îsâ, Hz. Meryem ve Hıristiyanlar hakkında şahitliği" konu başlıkları altında Kur'an hakkında bilgi vermekte, 9 ve 10. konularda ise Kur'an'dan Hz. Îsâ, Hz. Meryem ve Hıristiyanlık hakkında âyetler aktarmaktadır. ${ }^{55}$

Yazarın diğer eseri De statu Sarracenorum'un ise 24. "Kur'an nasıl oluşturuldu", 25. "Kur'an'ın muhtevası" ve 26. "Müslümanların Allah'ın Tevrat ve Incil'den sonra niçin Kur'an'ı gönderdiğine dair görüşleri" konu başlıkları doğrudan Kur'an hakkındadır. ${ }^{56}$ Devam eden 27-48. konular ise Hz. Îsâ, Hz. Meryem ve Hıristiyanlık hakkında Kur'an'dan aktarılan çok sayıdaki âyetlerden oluşmaktadır. ${ }^{57}$ Bu başlıkların bazılarında sadece âyetlere yer verilmiştir.

Bkz. Wilhelm von Tripolis, De statu Sarracenorum, 365.

Wilhelm von Tripolis, Notitia de Machometo, 195.

Wilhelm von Tripolis, Notitia de Machometo, 210-237. Arada kalan 8. konu ise cennet hakkında olup aynı zamanda birkaç âyet nakledilmiştir.

Wilhelm von Tripolis, De statu Sarracenorum, 334-341.

Wilhelm von Tripolis, De statu Sarracenorum, 341-361. William'ın, Notitia de Machometo'da tercüme ettiği âyetler şunlardır: Fâtiha sûresi; Bakara, 2/1-4, 253; Âl-i İmrân, 3/35-37, 42-43, 45-51, 55; Nisâ, 4/3, 155-158; Mâide, 5/46-47, 110, 112-115; Meryem, 19/16-33; Enbiyâ, 21/91; Rûm, 30/2-3; Zuhruf, 43/57-59, 63-64; Hadîd, 57/27; Saf, 61/14; Tahrim, 66/12; İhlâs, 112/1-4. Fâtiha ve İhlâs sûreleri hariç, diğer bazı âyetler biraz farklı biçimde De statu Sarracenorum'da da bulunabilmektedir. Bkz. Hartmut Bobzin, Der Koran im Zeitalter der Reformation Studien zur Frühgeschichte der Arabistik und Islamkunde in Europa (Würzburg: Ergon Verlag, 2008), 588. 
Bobzin, Notitia de Machometo'daki Kur'an tercümelerinin Robert von Ketton (ö. 1160) veya Marcus von Toledo'nun (ö. 1256) daha önceki Kur'an tercümelerinden farklı olduğunu ve doğrudan Kur'an'dan yapıldığını düşünmektedir. ${ }^{58}$ Engels ise, çevirilerin William'ın kendisine ait olduğuna dair tereddüt taşımaktadır. ${ }^{59} \mathrm{O}$, tercümelerin en azından bir kısmını başka kaynaklardan almış olabilir.

\subsection{Kur'an'ın Teşekkülü}

William'ın her iki eserinde üzerinde durduğu konulardan birisi, Kur'an'ın anlamı, muhtevası ve cem edilmesi hususudur. Onun en tuhaf görüşlerinden biri Kur'an'ın teşekkülü hakkındadır. O, De Statu Sarrazenorum'da "Kur'an nasıl bir araya toplandı" adlı 24. konuda Kur'an için "Alcoranum (el-Kur'ân)", "Meshaf (Mushaf)" veya "Hatine"60 denildiğinden söz etmekte ve yazılı veya sözlü olduğunu belirtmeksizin İslâm âlimlerine nispet ederek Kur'an'ın nüzûlü, muhtevası ve bilhassa cem'i hakkında genişçe nakillerde bulunmaktadır. ${ }^{61}$ William'ın devam eden 25. konusu da "Kur'an'ın Muhtevası" adını taşımaktadır. ${ }^{62}$ Onun Kur'an hakkındaki üçüncü konu başlığı (26. konu) ise "Sarazenlerin Tevrat ve Incil'den sonra Allah'ın niçin Kur'an'ı indirdiği hakkındaki görüşleri" şeklindedir. O, bu hususta İslâm âlimlerine dayandırdığı bazı bilgileri nakletmektedir. ${ }^{63}$ William, Kur'an hakkında İslâm âlimlerinden şöyle bir bilgi aktarmaktadır:

"Müslümanların âlimlerinin anlattıklarına göre, Hz. Muhammed 45 yaşlarında iken ${ }^{64}$, Cebrail adlı meleğin ona ilâhî istekleri bildirmek ve öğretmek suretiyle kendisinin Allah'ın bir peygamberi olduğunu açıklamaya başladı. Bu vahyolunanlar daha sonra onun ümmeti tarafından biraraya toplandı ve

Bobzin, Der Koran im Zeitalter der Reformation, 588.

Bobzin, Der Koran im Zeitalter der Reformation, 589. William'ın Arapça bilgisine dair Engels'in değerlendirmesi için bkz. Engels, Wilhelm von Tripolis, 85-89.

Engels, bu kelimenin gerçekte ne olduğunu tam olarak belirleyememiş, "hikmet", mühür anlamında "hatem", kutsal anlamında "haram" ve Kâbe'nin bir bölümü olan "hatim" anlamında olabileceğini belirtmiştir. Engels, Wilhelm von Tripolis, 434, Nr. 342. Prutz ise bu kelimeyi Latince "Harine"şeklinde kaydetmiştir. Bkz. Hans Prutz, Kulturgeschichte der Kreuzzüge, (Berlin: Königliche Hofbuchhandlung, 1883), 590.

1 Wilhelm von Tripolis, De statu Sarracenorum, 335-337. Ayrıca bkz. Raeder, Antworten auf den Islam, 64-65.

Wilhelm von Tripolis, De statu Sarracenorum, 337-339. Kur'an'da Hz. Peygamber'in isminin dört yerde (Âl-i İmrân 3/144; Ahzâb 33/40; Muhammed 47/2; Fetih 48/29) zikredildiği mâlumdur.

Wilhelm von Tripolis, De statu Sarracenorum, 339-341.

$\mathrm{Hz}$. Peygamber'e vahiy 40 yaşında iken geldiği bilinen bir husustur. Yazarın bu yanlış bilgiyi Müslümanlara nisbet etmesi anlaşılamamaktadır. 
böylece zikredilen kitabı oluşturdular. Fakat onlar bu kitabın (bildirdiklerinin) gerçek olduğunu ispat edemezler. Zira hakikat Katolik Hıristiyanların onu anlattıkları gibidir.

Muhammed'in ölümünden yaklaşık 40 yıl ${ }^{65}$ sonra, onun arkadaşlarından hayatta olanlar,'Muhammed vasıtasıyla Hacer ve İsmail'in soyundan gelen Arapların çocuklarına verilen, Allah'ın Kanunu ve Öğretisi' adını taşıyan bir kitap yazmayı görüşmek üzere bir araya geldiler. Oybirliğiyle alınan karar ile kitabı yazma ve biraraya toplama yetkisi, onlardan Effan'ın oğlu Esman (Osmân b. Affân) isminde birine verildi.

Fakat Osman bu iş için yetişmediğinden, itibar ve saygınlığı olan mümtaz kitabı bir araya getirmede kendisine yardımcı olabilecek, âlim kabul ettiği, ölüm korkusuyla Müslüman olan mutsuz ve zayıf birkaç Hıristiyan ve Yahudi âlimi seçti. Bunlar bir araya gelip Muhammed'in ne hayatında ne de öğretilerinde söz edilmeye veya övülmeye değer hiçbir şey bulamadıklarından, yalancılığın ve hilekârlığın kralı gibi, edebî bir kompozisyona hâkim olmayan, öğretme sanatından hiçbir şey anlamayan, yazarken filozofun, tarihçinin ya da peygamberin izini takip etmeyen, aksine daha çok falcının peşinden giden, ne ahlâkı, ne bilgiyi, ne tarihi ve ne de inancı öğretmeyen kimseler olarak söz konusu kitabı, alıntıları bir araya getirerek yazdılar.

Bu sebeple şöyle denilmesi yerindedir: Bu kitap, diğer kuşların renkli tüylerini ödünç alan ve onlarla süslenmiş olan, bir araya toplanmış kuşların meclisine giren ve cennetten gelmiş bir kuşmuş gibi itibar gören, fakat kuşlar onun tüylerini süküp alınca garip tüylerle süslenmiş bir karga olduğu, güzel tüylerden mahrum olduğu ortaya çıkınca, kahkahalara yol açan bir karga gibidir. Yani sözü edilen bu kitap, kara bir karga gibidir. Çünkü bu kitapta Muhammed'e ait sadece karanlık ve çirkinlik vardır. Fakat Kitab-ı Mukaddes'ten alınmış güzel ve parlak sözlerle süslenmiş olduğu için, o ilâhî bir kaynaktan geliyormuş gibi görünmekte ve bu sebeple ona hayran olunmakta ve övülmektedir."66

Yazar, Müslümanların Kur'an'ın Hz. Peygamber 45 yaşında iken vahyolunduğunu söylediklerini ileri sürmekte, gerçekte Kur'an'ın vahiy olduğunu reddederek Victor Tolan, Saracens: Islam in the Medieval European Imagination, (New York: Columbia University Press, 2002), 207) bu sayıyı 15 yıl olarak zikretmiş̧tir. Hatanın nereden kaynaklandığı belirlenememiştir. 
Resûlullah'ın vefatından kırk yıl sonra Hz. Osman tarafından mühtedi Yahudi ve Hıristiyanlara yazdırıldığını ve Tevrat ve İncil'e dayandığını iddia etmektedir. Neredeyse her Müslümanın bildiği bir bilgi olan Hz. Peygamber'in kırk yaşında peygamber olduğu hususunun yanlış aktarılmasının sebebi belirlenememiştir. Doğu ve Batı'da Kur'an daha çok Sergius'a veya Bahîra'ya nispet edilirken o yeni bir kaynak senaryosu uydurmuştur. William'dan önce buna benzer bir görüşe sahip birini şimdilik bilmiyoruz.

\title{
2.2. Kur'an'ın Muhtevası
}

Bu hususta müstakil bir konu başlığına yer vermiş olan William, "Kur'an'ın Muhtevası Hakkında (25. konu)" adlı bölümde şöyle der:

\begin{abstract}
“Müslümanların Kur'an veya Mushaf olarak isimlendirilen kitabı, Yaratıcı hakkında çok övgü ihtiva eder. Bir çok yerde Allah'ın gücü, bilgisi, ihsanı, merhameti, adaleti, hakkaniyeti ve sabrı övülür, Allah'a inanan ve iyilik yapanlar medhedilir, fakat imanın ve dinin ne olduğu, kimin mü'min veya kâfir olduğu açıkça belirtilmez. Kur'an Meryem oğlu Îsâ'yı bütün insanların üzerinde medhetmekte ve yüceltmekte, ilâhî güç ve Tanrı'nın ruhuyla bâkire olarak doğuran (ve bâkire) kalan Hz. Meryem'i de bütün kadınların üzerinde övmekte ve yüceltmektedir. Kur'an Tevrat, İncil, Zebur ve Peygamberler Kitabı olmak üzere dört kitabın gökten indirildiğini söyler ve bunların beşincisini "Alcoran-el-Kur'ân" olarak isimlendirir. Buna karşılık Kur'an, Muhammed'i yalnızca iki yerde zikreder ${ }^{67}$ ve onun hakkında hiçbir medhiyede bulunmaz. Fakat Kur'an Rab Îsâ'dan harika övgüyle bahseder. Aynı şekilde onun annesi Meryem ve Hıristiyan denilen onun takipçileri hakkında da benzer şekilde medhiyelerde bulunur." ${ }^{\prime 6}$
\end{abstract}

William, Kur'an'da Hz. Peygamber'in isminin kaç defa zikredildiğini doğru bir şekilde belirtmediği gibi muhtemelen bilinçli olarak Resûlullah'ın konumunu ifade eden âyetleri de görmezden gelmektedir. Hâlbuki Kur'an'da Hz. Peygamber'in ahlâkını, imanını ve ibadetlerini öven pek çok âyet bulunmaktadır. ${ }^{69}$ Onun,

69 Örnek olarak bkz. Âl-i İmrân, 3/31, 32, 164; Tevbe, 9/128; Enbiyâ, 21/107; Ahzâb, 33/21; Kalem, $68 / 4$. 
Kur'an'ı ayrıntılı olarak incelemediği muhtemel gözükmektedir. O, Kur'an'ı sadece "Hz. Îsâ, Hz. Meryem ve Hıristiyanları öven" bir kitap olarak görmektedir.

William'ın Kur'an hakkında bilgi verdiği diğer bölüm ise 26. konu olan "Sarazenlerin Tevrat ve Incil'den Sonra Allah'ın Niçin Kur'an'ı Gönderdiğine Dair Görüşü" adını taşımaktadır. O burada "Müslümanların âlimleri der ki" ifadesiyle İslâm âlimlerine dayandırdığı şu bilgileri nakletmektedir:

"Allah, insanları doğru yola iletmek için peygamber ve kitap göndermiştir. Gerçek Tanrı olarak tanınması ve saygı gösterilmesi için İbrahim'den sonra İsrailoğullarına Tevrat'ı vermiş, fakat onlar onu korumayı ihmal edip tahrif ettikleri için Allah insanlara kendisi hakkındaki bilgiyi iletmek için Tevrat'tan sonra İncil'i indirmiştir. Fakat İsmail vasıtasıyla İbrahim'in soyundan gelen ve İshâk'ın soyundan olan Yahudilerden daha büyük bir halk olan Araplar, peygambersiz kalmışlardır. Çünkü onlara ne Mûsâ'nın Tevrat'ı ne de Hıristiyanlık inancını bildiren İncil ulaşmıştır. Bu yüzden adaleti ve rahmeti gereği Allah onlara kendi soylarından ve kendi dillerini konuşan bir peygamber göndermiştir. Yahudiler Hz. Mûsâ'yı ve Hıristiyanlar Hz. Îsâ'yı takip etttikleri gibi Müslümanlar da Hz. Muhammed'i takip etmelidirler. Müslümanlar, Yahudilerin Tevrat'ı ve Hıristiyanların da İncil'i tahrif ettiklerini, buna karşılık kendilerinin ilâhî kitapları olan Kur'an'ı tam bir şekilde koruduklarını söylemek suretiyle kendilerini Yahudilerin ve Hıristiyanların önünde tutuyorlar."70

William, anlaşılmaz bir şekilde başka yerlerde Müslümanlardan veya İslâm âlimlerinden gerçek dışı bilgiler aktarırken onun bu bölümde naklettiği bilgiler İslâm kaynaklarına uygundur. Onun gerçek dışı aktardığı bilgilerin bir kısmı sıradan insanlara veya Doğu Hıristiyanlarına dayanıyor olabilir.

William, Notitia de Machometo'da "Muhammed'in Kitabı Nasıl ve Ne Zaman Geldi (5. konu)" başlığında ise Kur'an'ın cem'i hususunda farklı bir izahta bulunmaktadır. Buna göre Hz. Peygamber'in ölümünden kırk sene sonra, onun arkadaşlarından veya takipçilerinden -bunlar halkın önde gelenlerinden on kişi idi (ve bunlardan)- yedi kişi henüz hayatta idi. Onların elinde Hz. Peygamber'den kalmış olan bir şeriat yoktu. Fakat onun adı, şöhreti ve gücü, Allah’ın bir şeriatı gibi, tahmin edilemeyecek kadar parlak ve yaygın idi. Yine Hz. Peygamber'in bağlıları, şeriatsız yönetilmemeleri için, "Muhammed'in Şeriatı” adını alacak bir akide oluştur- 
mayı planladılar. Zira Allah'a inanan diğerlerinin bir şeriatları vardı. Yahudilerin Tevrat'ı, Hıristiyanların ise İncil'i mevcuttu. Şamlı olan Affân'ın oğlu Osman'dan başka onlar ne okuma biliyorlar ne de yazıdan anlıyorlardı. Müslümanlar, Osman'a bir komisyon kurma ve bu komisyona İslâm'a geçmiş olan Yahudi ve Hıristiyan bilginlerden yardım alma görevi verdiler. Komisyon, "Cebrail Tarafından vahyolunan Peygamber Muhammed'in Şeriatı ve Kitabı" adını taşıyan Arapça bir kitap yazacaktı. Hz. Osman, Hz. Peygamber'i gören veya dinleyen kişilerden Peygamber hakkında öğrendikleri her şeyi bu kitaba koyacaktı.

William'a göre "hakikatten ayrılmış" (!) ve İslâm'a geçmiş olan "bu kişiler", söz konusu kitabı yazmak için bir araya çağırıldı. Onlar, adı geçen Peygamber'in söz ve davranışları arasında övgüyü hak eden hiçbir hikmet, fazilet, maharet ve makul bir şey bulamamalarına rağmen, kurnazca bir hileyle, onun adını zikretmeksizin Peygamber'i harika bir şekilde medhettiler. William devamla onların bu kitapta $\mathrm{Hz}$. Peygamber'in adını sadece bir yerde zikrettiklerini ileri sürmekte ve burada onu medhetmeksizin "Muhammed sadece Allah'ın bir elçisidir. Ona inananlar şunu kabul etmeliler; o ölür veya öldürülürse ve bunun üzerine birisi dininden dönerse, onun hatası Allah'a zarar vermez (Âl-i İmrân 3/144)" dediklerini zikretmektedir. Onun bu âyeti yüzeysel tercüme ettiği görülmektedir. William, Kur'an'da Hz. Mûsâ ve Hz. Îsâ'nın ise birçok yerde övüldüğünü, "Allah’ın Kelimesi” olarak isimlendirildiğini ve Hz. Îsâ'ya hakaret edenlerin ölümle cezalandırıldığını söylemektedir. Yazar, diğer bazı kişilerin de Hz. Osman gibi kitaplar yazdıklarını, fakat derin etkiye sahip, büyüleyici stiliyle ve edebî dil üstünlüğü sebebiyle Osman'ın adıyla anıldığını söylemektedir. Böylece bu kitap, ona göre sanki Müslümanların Hz. Muhammed'den duyduklarından ve onda gördüklerinden oluşturulmuş gibi kabul edilmiştir.

William, diğer bazılarının da (Peygamber'in sözlerini ve fiillerini) topladıklarını ve bunlardan kitaplar yazdıklarını, bu sebeple Müslümanlar arasında 200 yıl süren tartışmalar olduğunu, sonunda Hz. Osman'ın yazdığının muteber kabul edildiğini ve buna "Peygamber'in Şeriatı, Müslümanların Âmentüsü, Peygamber Muhammed'e Allah Tarafından Vahyedilen Kitap, Allah'ın Kitabı ve Belgesi" adını verdiklerini, "Alcoran (Kur'an)" veya "Forcan (Furkân)" dedikleri bu kitabı diğer dört ilâhî kitapların, Tevrat, Zebur, İncil ve Peygamberler Kitabı'nın arasına beşinci olarak soktuklarını ileri sürmektedir.71 
William’ın Hz. Osman’ın Şamlı olduğunu iddia etmesinin sebebi onun daha önce ticaretle uğraşmasına dayanabilir. Onun Hz. Ebû Bekir zamanında Kur'an'ın cem'ini değil de Hz. Osman zamanındaki nüsha çoğaltmayı söz konusu etmesinin sebebi de anlaşılamamaktadır. Yine onun Kur'an'ın cem'i ile kıraat farklılıklarını birbirine karıştırdığı muhtemel gözükmektedir. Kur'an için uzun bir isim zikretmesi de Kur’an'ın özelliklerini veya sözlü kaynakların etkisini çağrıştırmaktadır. Yine onun Kur'an'la hadislerin yazılma sürecini de karıştırdığından söz edilebilir. Zira iki yüz yıl gibi bir süreden bahsetmesi hadislerle ilgili veya fıkhî tartışmaları hatıra getirmektedir. $\mathrm{O}$, suhuf için ise "Peygamberler Kitabı" ifadesini kullanmıştır. William'ın Kur'an'ın teşekkülüne dair anlattıkları nev'i şahsına münhasır gözükmektedir. İki eser arasında da bazı farklı senaryolar mevcuttur.

William, "Tanrı́nın şeriatı olarak gökten gelen beş kitap; Müslümanlar kendi kitapIarının kutsal kitaplar arasında olduğunu iddia ediyorlar" adlı 6. konuda "Bu kitabın âlimleri şöyle diyorlar" diye başlayıp Müslümanların, Yahudilerin Tevrat'ı, Hıristiyanların da İncil'i tahrif ettiklerinde yeryüzünde Allah'ın hak bilgisinin kalmadığı için Allah'ın Kur'an'ı indirdiğini, bu kitabın diğerlerinde bulunanları da ihtiva ettiğini söylediklerini aktarmaktadır. ${ }^{72}$ Burada onun bir tefsirden mi veya devrindeki herhangi bir şahıstan mı nakilde bulunduğu anlaşılmamaktadır. Ortaçağ'da Batı'da İslâm ve Hz. Peygamber hakkında aktarılan bilgilerin kaynakları, Kur'an dışında genelde belirtilmemiştir. Bunun sebebi, söz konusu kitaplara ulaşmanın zorluğu olabilir. İslâm’a dair bilgiler için “kaynak bilinci”nin de oldukça geç oluştuğunu söyleyebiliriz.

\subsection{Kur'an Hakkında Diğer Bazı Görüşleri}

William, yukarıda geçtiği üzere Kur'an'ı kuşlar arasında kargaya benzetmektedir. ${ }^{73}$ Öyle anlaşılıyor ki, onun zamanındaki teolojik tartışmalarda sık sık Müslümanlara karşı bu ifade kullanılmakta ve Kur'an'ın Tevrat ve İncil'e dayandığı iddia edilmektedir. Hıristiyanların bu iddiasını Hz. Peygamber dönemine kadar götürmek mümkündür. Zira müşrikler tarafından Kur'an’ı Resûlullah’a Ehl-i kitap’tan birinin öğrettiği iddia edilmiştir. ${ }^{74}$ 
William, Kur'an'dan yaptığı nakillerin Müslümanların elindeki Kur'an'dan olduğunu göstermek için Notitia de Machometo'da Kur'an'ın Önsözü/Girişi Nasıldır adıyla bir bölüme (7. konu) yer vermiş ve burada Fâtiha sûresinin tamamını ve Bakara sûresinin ilk dört âyetini tercüme etmiştir. $\mathrm{O}$, bununla Kur'an'ın gerçek metnini kullandığını ispat etmek istediğini söylemekte ve okuyucunun eline bir şekilde bir Kur'an tercümesi geçerse, Müslümanların elinde bulunan Kur'an'la aynı olduğunu görüp karşılaştırabilmesi için bunu yaptığını belirtmektedir. Onun bu tercümede metne sadık kaldığını söyleyebiliriz. Müellif, ilk sûre olarak kabul etmediği Fâtiha sûresini “Önsöz/Giriş” olarak nitelendirmiş ve Bakara sûresinin adını zikrederek onu ilk sûre saymıştır.

Yazar, "Elif Lâm Mîm" hakkında da ilginç bir değerlendirmede bulunmuştur. O, bunu tercüme etmeksizin "ALEM" şeklinde zikredip bunun anlamını kimsenin bilmediğini belirttikten sonra bu harflerin birleştirildiğinde "üzüntü/ızdırap" anlamında "elem" ifadesini oluşturacağını, bu kitaba bağlı olanlardan hiçbir kimsenin bunu telaffuz etmeye cesaret edemediğini, çünkü bunu yaparlarsa onların ızdıraptan ve cehennem azabından korktuklarını söylemektedir. ${ }^{75}$ Onun, bu tarz naklettiği bilgileri Müslümanlarla müzakere etmediğini söylemek mümkündür.

William tercüme ettiği âyetlerde bazen ihtisarda bulunmuştur. Nitekim İhlâs sûresinin tercümesinde bunu görmek mümkündür. O, İhlâs sûresini ilk âyeti atlayarak tercüme etmiştir. ${ }^{76}$

\subsection{Kur'an'ın Hıristiyanlık için Delil Olarak Kullanılması}

William'ın Kur'an hakkında bahsedilmesi gereken diğer bir tavrı ise başta Hz. Îsâ ve Hz. Meryem hakkında olmak üzere Hıristiyanlıkla ilgili birçok âyeti nakletmesidir. O, Hz. Meryem'in doğumu, büyümesi, eğitilmesi, duası, Hz. Îsâ'nın doğumu, annesini savunması, ölümü hakkındaki tartışmalar, mucizeleri gibi hususlarda çok miktarda âyet nakletmektedir. ${ }^{77} \mathrm{O}$, Notitia de Machometo'da ise MüslümanIarın Kitabının Hz. Îsâ, Hz. Meryem ve Hıristiyanlar Hakkındaki Şahitlikleri (9. ve

Wilhelm von Tripolis, Notitia de Machometo, 219. O, diğer hurûf-u mukattaalar hakkında ise bir görüş belirtmemiştir.

77 Bkz. Wilhelm von Tripolis, De statu Sarracenorum, 343-360. 
10. konu) adlı bölümlerde peşpeşe 19 âyet nakletmektedir. ${ }^{78}$ Onun bu âyetleri kendisinin mi tercüme ettiği yoksa başka tercümelerden mi istifade ettiği hususunda kesin bir şey söylemek mümkün değildir. ${ }^{79}$ William'ın naklettiği âyet sayısı bununla sınırlı değildir. O, De statu Sarracenorum'da Kur'an'ın Hz. Îsâ, Hz. Meryem ve Hıristiyanlar hakkında birçok bilgi aktardığınu belirtir ve bu bölümlerde çok sayıda âyet nakleder. Hatta bazı bölümlerde sadece âyetler yer almaktadır. ${ }^{80}$ Onun, Kur'an'ın Hıristiyanlığa dayandığını veya Hıristiyanlığı desteklediğini ispat için Kur'an'dan nakilde bulunduğunu söylemek mümkündür. $\mathrm{O}, \mathrm{Hz}$. Îsâ ve $\mathrm{Hz}$. Meryem hakkında Tevrat ve İncil'e muhalif olan âyetleri ise görmezden gelmekte, polemik amaçlı da olsa bu âyetlere yer vermemektedir.

\subsection{Kasıtlı Hatalı Kur'an Tercümesi}

Yazar, âyetleri doğrudan Kur'an'dan aktardığını belirtmesiyle birlikte, Hıristiyanlık lehine yaptığı yorumlar bir tarafa, bazı âyetleri bilmeden veya kasıtı olarak yanlış tercüme etmiştir. Bunlardan en önemlisi, onun birkaç yerde tekrarladığı çok kadınla evlilik hakkındaki âyeti çarpıtmasıdır.

William, Müslümanların Temel Innançları ve Öğretileri bölümünde (51. konu) "Eğer birisi onlara Muhammed'in riâyet edilmesini istediği temel hayat ilkelerinden sorarsa şöyle derler" diyerek şu ifadelere yer vermektedir: "Sen iki, üç, dört -yani dokuzeş sahibi olabilirsin. Zenginlik açısından gücün yettiği kadar cariye sahibi olabilirsin. Eğer bir kadın senin hoşuna gitmiyorsa, ona boşanma hükmünü ver ve bırak gitsin. Sana elin altında bulunanları bir merkeb veya bir atı kullandığın gibi kullanma hususunda izin verilmiştir."181 $\mathrm{O}$, neredeyse bütün reddiye ve polemik eserlerinde yer alan dört kadınla evlenilebileceği hususuna, âyetten söz etmeksizin yer vermiştir. Ancak onun burada Nisa, 4/3. âyetine işaret ettiği ve âyette zikredilen rakamları toplayarak dokuz kadınla evlenilebileceğini belirttiği anlaşıımaktadır. O, bu konuya Notitia de Machometo'da da yer vermekte, fakat burada zikrettiği metin biraz farklılık arz etmektedir. ${ }^{82} \mathrm{O}$, burada da rakamları toplayarak Müslümanların

Wilhelm von Tripolis, Notitia de Machometo, 223-237.

Bobzin tercümelerin William'a ait olduğunu düşünürken (Bobzin, Der Koran im Zeitalter der Reformation, 588) Engels onun Arapça bildiğinden emin değildir (Engels, Wilhelm von Tripolis, 85-89). Bkz. Wilhelm von Tripolis, De statu Sarracenorum, 341-361 (27-48. Bölümler).

Wilhelm von Tripolis, De statu Sarracenorum, 363; Raeder, Antworten auf den Islam, 67. O, Kur'an'da olmayan dokuz eşe izin verildiği iddiasını Kur'an'a nispet etmiştir.

Wilhelm von Tripolis, Notitia de Machometo, 217. Ayrıca bkz. A.g.e., 243. William bu hususu üç 
dokuz kadınla evlenebileceğini ifade etmektedir. Batı'da Aydınlanma dönemine kadar hem Kur'an hem de İslâm kaynaklarının tercümelerinde bol miktarda kasıtlı-kasıtsız hatalar bulunmaktadır.

Trablusşamlı William'ın Kur'an'dan yüzeysel yaptığı bir nakil ise şöyledir:"Kur'an'da birçok yerde şu ifade vardır: "Kötülükleri bırak ve iyilik yap. Kim bunu yaparsa cennete girer." O, bunu "Müslümanlar şu süslü ve boş sözü söylemekten başka bir şey bilmezler" diyerek aktarmakta ve bu sözün Kur'an'da birçok yerde bulunduğunu iddia etmektedir. ${ }^{83}$

William'ın Kur'an'la birlikte tefsirlerden de nakilde bulunması muhtemel gözükmektedir. Ancak bunun bir esere dayandığı açıkça belirtilmemektedir. Nitekim o, "Hz. Îsâ'nın Ölümü Hakkında Yanlış Düşünceye Dair" (44. konu) adlı bölümde "Bu hususta Kur'an müfessirleri şöyle diyorlar" şeklinde konuya giriş yapmakta ve Müslümanların, Yahudilerin Hz. Îsâ'yı çarmıha germediklerini söylediklerini aktarmaktadır. $^{84}$

\subsection{Kur'an'a Yöneltilen Eleştiriler}

William'ın Kur'an'a yönelttiği eleştirilerden biri onu Kitab-ı Mukaddes'le kıyaslayıp diğer dört kitapta emir ve yasaklar bulunduğu halde, Kur'an'da olmadığıdır. O, Tevrat'ta 613 kanun olduğunu, bunlardan insan vücudundaki kemik sayısı kadar olan 248 adet emir bulunduğunu, bir yılın günleri kadar (365 adet) olan kalanlarının ise yasakları oluşturduğunu söyler. William, polemik üslûbuyla "Fakat Senin kitabında inançla veya güzel ahlâkla ilgili bir tek kanun yoktur" diyerek karşılaştırma yapmakta, Kur'an'da birçok yerde "kim inanır ve salih ameller işlerse, mutlu kimselerden olacaktır" denildiğini, bunun ise ne inanç ne de ahlâk öğrettiğini iddia etmektedir. ${ }^{85}$

farklı yerde zikretmiş olup her biri diğerlerinden bazı lafız farklııı̆ı taşımaktadır. Batı'da polemik vasıtası yapılan bu âyetin yine sayıların toplanması yoluyla "on kadın" olarak yorumuna dair bkz. Roggema, The Legend of Sergius Bahira, 519, Dipnot: 142. William'ın kadınlara hayvanlar gibi muamele edileceğine dair iddialarının reddiye ve apolojik eserlerde pek rastlanmadığını belirtmeliyiz.

83 Wilhelm von Tripolis, Notitia de Machometi, 255. William bu ifadelerinde iman edip salih amel işleyenlere cennet vadedilen âyetleri kasdetmektedir. Bkz. Bakara, 2/25, 82, 277; Nisâ, 4/57, 122, 124; A'râf, 7/42; Yunus, 10/9; İbrahim, 14/23; Hac, 22/14, 23.

85 Wilhelm von Tripolis, Notitia de Machometi, 243. William'ın Kur'an'da ahkâm bulunmadığını iddia etmesi de ancak kasıt, çarpıtma veya görmezden gelme sonucu olabilir. Kur'an'ın tercü- 
William, Kur'an'a “Hak kitap” denilemeyeceğini, zira Kur'an'da Hz. Îsâ'nın annesi Hz. Meryem'in, Hz. Mûsâ ve Hârûn'un kardeşi olarak zikredildiğini, hâlbuki ikisi arasında 2000 yıldan fazla bir zaman olduğunu iddia etmektedir. Yine Kur'an'da hiçbir doğru bilgi bulunmadığını, kendisiyle çelişerek sadece Hz. Meryem ve Hz. Îsâ hakkında zikrettiği 19 âyetin hakikat olduğunu polemik üslûbuyla ileri sürmektedir. Kur'an'da birçok peygamberin saygıyla anlatıldığını, Hz. Muhammed'in ise sadece bir yerde övülmeksizin zikredildiğini ileri sürmektedir. ${ }^{86}$

Yazar, Kur'an'ın muhtevasını kötülemek için Kur'an'da şu sözün bulunduğunu iddia etmektedir: "Allahı́n düşmanına Allah'ın bir delilini göster. Bunu yaptıktan sonra onu yakala ve öldür." 87 Kur'an'da böyle bir âyet olmadığı malûmdur. Ancak onun, kıtâl âyetlerini kasdetmesi mümkündür. William, Kur'an'ın önceki inanç ve ahlâkı bozduğunu iddia ettiği gibi, bu yüzden birisinin Kur'an'da nelerin bulunduğunu, Kur'an ve Peygamber'in ne dediğini sormasının yasak olduğunu, böyle bir şey soranın öldürüldüğünü iddia etmektedir. Yine onun iddiasına göre kâdî denilen İslâm âlimlerinden biri Kur'an okur veya öğretirse kılıcını üç-dört parmak genişliğinde kınından çıkarır ve onu tehdit işareti olarak tutar. Birisi Kur'an'ın emrine karşı çıkarsa orada öldürülür. ${ }^{88}$ William, Kur'an'da sadece Tevrat ve İncil'den alındığını iddia ettiği bilgileri doğru kabul etmektedir.

\section{William of Tripoli'nin Sonraki Dönem Oryantalistik Düşünceye Etkisi}

Haçlı seferleri, Batı́nın İslâm'ı tanımasına katkısıyla birlikte ${ }^{89}$ bilhassa Hz. Peygamber hakkındaki olumsuz bilgilerin daha da yayılmasına yol açmıştır ve bunda Haçlı seferlerinin görgü şahidi olan William'ın da katkısı vardır. ${ }^{90}$ Onun söz ko-

melerinin sınırlı olduğu bir zamanda Batı'da Kur'an hakkında anlatılanların ne ölçüde gerçek dışı olduğu açıkça görülmektedir. Burada tarih boyunca Müslümanların Kur'an'ı başka dillere tercüme etmemiş olmalarının sonucunu da görmekteyiz.

Wilhelm von Tripolis, Notitia de Machometi, 247-249. O, başka bir yerde ise Hz. Peygamber'in Kur'an'da iki yerde geçtiğini iddia etmiştir.

87 Wilhelm von Tripolis, Notitia de Machometi, 217.

88 Wilhelm von Tripolis, Notitia de Machometi, 217-219.

89 ìlk Haçlı seferinden sonra ilerleyen zamanlarda Kur'an, Hz. Peygamber ve İslâm hakkında doğru bilginin yayılması hakkında bkz. Dana Carleton Munro, Munro, Dana Carleton, "The Western Attitude Toward Islam During the Period of the Crusades", Speculum A Journal of Mediaeval Studies 6/3 (July, 1931), 329-340. Haçlı seferlerinin oryantalistik düşünceye etkisine dair bkz. İbrahim Kutluay, "Oryantalistik Düşünceye Etkisi Açısından Haçlı Seferleri", Eyyûbîler'de Siyasi ve Ekonomik Iliş̧iler, Ed.: Abdulhailm Oflaz, Rumeysa Seven vd., (İstanbul: Hiperlink Yayınları, 2020), 190-209. 
nusu eserlerinin birçok el yazmasının bulunması, onların oldukça yaygın ve etkili olduğunu göstermektedir. ${ }^{91}$

William'ın her iki eseri, sonraki bazı yazarlar için müracaat kaynağı olmuştur. Notitia de Machometo'dan istifade edenlerin başında Nikolaus von Kues (ö. 1464) ve eserlerinden doğrudan iktibaslarda bulunan Felix Fabri (ö. 1502) bulunmaktadır. Mezkûr eserin yazmaları sadece Almanya'da yayılmıştır.92 Notitia'nın muhtevası Nikolaus von Kues tarafından çok iyi biliniyordu zira o bu eserden bir nüshaya sahipti. O, Ciribratio Alkorani adlı eserini yazarken Notitia'dan çok faydalanmıştır. ${ }^{93}$ Felix Fabri'nin, içki yasağına dair Hz. Peygamber'in hizmetçisi tarafından onun kılıcıyla yeğeninin öldürüldüğünü anlattığı benzer bir uydurma daha söz konusudur. ${ }^{94}$ Yine İslâm hakkında eser yazmış olan Ricoldo (ö. 1320), Bahîra efsanesini büyük ölçüde aynen aktarmış olan Giovanni Villani (ö. 1348), İtalyan devlet adamı Coluccio Salutai (ö. 1406), Bahîra hadisesini benzer şekilde aktaran İngiliz tarihçi Ranulph Higden (ö. 1363) William'ın De statu Sarracenorum adlı eserinden etkilenen kişiler olarak gösterilmektedir. ${ }^{95}$ Fransız seyyah Jean de Mandeville (ö. 1372) İslâm dünyasına dair bilgileri William'ın eserinden aktarmıştır. ${ }^{96}$ Zira o, William'ın De statu Sarracenorum adlı eserini çok iyi tanıyan ve kullanan şahıslardan biridir. ${ }^{97}$ Hz. Peygamber'in hocası olarak gösterilen Bahîra ve Kur'an'ın cem'i hususunda William'ın eserleri Batı'daki kaynaklardan oldukça farklı bilgiler sunmaktatır. Yine Hz. Ömer ve Memlük sultanı I. Baybars hakkında medhedici ifadelere yer vermekle diğer eserlerden farklılık göstermektedir.98

Diğer taraftan Prutz, 500 yıl gibi uzun bir zaman geçmesine ve Endülüs'te Müslümanlarla Hıristiyanlar yıllarca bir arada yaşamalarına rağmen 13. asrın ikinci yarısına kadar Kur'an ve İslâm hakkında bilgisizliğin devam ettiğini belirtmekte ve İslâm dünyasında uzun süre yaşayıp İslâm hakkında eser yazmış olan Ricoldo ve William'a işaret etmektedir. ${ }^{99}$ 
William'ın eserleri, Batı'da Kur'an'ın Allah tarafından gönderilen vahiy yerine bir ineğin boynuzları arasında gelen veya bir güvercinin $\mathrm{Hz}$. Peygamber'in yanına gelerek kulağına söylemesi şeklindeki “yalancı mucize” yerine Kur'an'ın Hz. Peygamber'den kırk sene sonra Hz. Osman başkanlığında kurulan komisyonla korkudan Müslüman olmuş Yahudi ve Hıristiyan âlimlerinin Tevrat ve İncil'den aldıkları bilgilerle oluşturulduğu iddiasını Batı'ya taşımıştır. ${ }^{100}$ Kur'an'ın Tevrat ve İncil'e dayandığı iddiasını ileri süren başka yazarlar da vardır.

Avrupa'da Haçlı seferlerinden sonra İslâm ve Hz. Peygamber hakkındaki olumsuz ve gerçek dışı bilgiler yerine kısmen doğru bilgiler artmıştır. ${ }^{101}$ William'ın eserleri bazı doğru bilgileri ihtiva etmektedir.

\section{Değerlendirme ve Sonuç}

Haçlı seferleri esnasında veya muhtelif sebeplerle Doğu Latin/Haçlı devletlerinde bulunan şahıslarla Müslüman âlimlerin münasebetleri ve eserlerinde buna dair verdikleri bilgilerin oryantalizm açısından araştırılması gerekmektedir. Nitekim William'dan başka İslâm dünyasında kalmış veya Haçlı devletlerinde ikamet etmiş ve daha sonra Avrupa'ya dönmüş olup İslâm ve Hz. Peygamber hakkında yazdıkları eserlerle Batı'da İslâm ve Hz. Peygamber imajının oluşmasında etkili olan birçok kişiden bahsedilmektedir. Meselâ; Kudüs'te yaşamış olan William of Tyre (ö. 1183), bir süre Ortadoğu'da dolaşmış olan Magister Thietmarus (ö. 1217 sonrası), beşinci Haçlı seferine katılmış ve gözlemlerini yazmış olan Oliver of Paderborn (ö. 1227), Akka bişofu James of Vitry (ö. 1240), bir süre Tunus'ta kalmış olan Raymundus Martini (ö. 1284), Marsilya bişofu olup üç yıl Haçlı devletlerinde kalmış olan Benedictus de Alignano (ö. 1268), uzun süre Bağdat'ta kalmış olan Riccoldus de Monte Crucis (ö. 1320), Kudüs'e hac seyahatinde bulunmuş olup Müslümanlarla görüşmeler yapmış olan James of Verona (ö. 1335) ve Fas'ta bulunmuş olan Alfonsus Bonihominis (ö. 1353), William of Tripoli gibi yazdıkları eserlerde İslâm'dan ve Hz. Peygamber'den bahsetmiş olan kişilerdir. ${ }^{102}$

100 Klueting, “Quis fuerit Machometus", 301.

101 Haçlı seferleri öncesinde Batı́nın İslâm ve Hz. Peygamber hakkındaki düşünceleri ve bunun değişmeye başlaması hakkında bkz. Jeremy Daniel Pearson, "The Islamic World and the Latin East: William of Tripoli and his Syrian Context", (PhD diss., University of Tennessee, Knoxville (ABD), 2018), 21-25. William'ın buna olumlu katkısına dair bir değerlendirme için bkz. Klueting, "Quis fuerit Machometus", 301-302.

102 Bu kişiler ve eserleri hakkında bkz. Michelina De Cesare, The Pseudo-Historical Image of the Prophet Muhammad in Medieval Latin Literature, 171, 206, 215, 221, 278, 337, 381, 459, 467. 
Araştırılması gereken diğer bir husus ise, Dominikenlerle Fransiskenlerin veya Doğu'da misyonerlik yapan Dominikenlerle Avrupa'dakilerinin eserlerinde $\mathrm{Hz}$. Peygamber hakkında farklı veya aynı bilgilerin bulunup bulunmadığının karşılaştırılmasıdır. Mesela William'dan kısa bir süre sonra ölmüş olan Dominiken tarihçi John Colonna (Iohannis de Columna)'nın (ö. 1340?) Mare Historiarum adlı eserinde Kur'an ve Hz. Peygamber hakkında anlattıkları birbiriyle örtüşmemektedir. ${ }^{103}$ Misyonerlik maksadıyla Doğu'da kalmış olan Dominiken ve Fransiskenlerin Avrupa'da Hz. Peygamber imajına nasıl bir katkıda bulundukları araştırılması gereken bir husustur. Yine bu şahıslarla İslâm âlimlerinin münasebetlerinin tespitinin de önemli olduğunu belirtmeliyiz. Meselâ, Dımaşk ve Kahire'de yaşamış olan ve Uyûnü'l-enbâ fî tabakâti'l-etıbbâ adlı eserin yazarı meşhur hekim İbn Ebî Usaybia (ö. 668/1269) William'la aynı dönemde yaşamış olup onun Hıristiyan hekimlerle münasebetleri olmuştur. ${ }^{104}$ Ebû Şâme el-Makdisî'nin (ö. 665/1267) Nûreddin Mahmud Zengî ve Selâhaddîn-i Eyyûbî hakkındaki Kitâbü'r-Ravzateyn'în ve Üsâme b. Münkız'ın (ö. 584/1188) Kitâbü'l-itibâr adlı eseri, Kudüs'ün fethinden sonra 584'te (1188) Dımaşk'ta Selâhaddîn-i Eyyûbî ile görüşen ve Hittîn Savaşı́nın cereyan ettiği alanı gezen, aynı yıl hükümdarın Antakya Prinkepsliği'ne karşı düzenlediği sefere askerlerin arasında bir tarihçi olarak katılmış olan ${ }^{106}$ İzzeddin İbnü'l-Esîr'in (ö. 630/1233) el-Kâmil fi't-târîh'i Müslümanlarla Haçlılar arasındaki ilişkiler hakkında önemli kaynaklardandır. ${ }^{107}$ Haçlı devletlerinde Müslümanlarla bir kısmı Avrupalı olan Hıristiyanlar iki yüz yıla yakın birlikte yaşamışlardır.

William, özellikle Hz. Peygamber'in Bahîra ile münasebetleri ve Kur'an'ın cem'i gibi bazı konularda başka eserlerde pek görülmeyen hayal mahsûlü değerlendirmelerde bulunmuştur. Ona göre Hz. Peygamber, Bahîra'yı öldürmüş, ayrıca

103 Bkz. Michelina Di Cesare, "New Sources for the Legend of Muhammad in the West", East and West 58 (2008), 25-29.

104 Eseri ve hayatı için bkz. Mahmut Kaya, "Ibn Ebû Usaybia", Türkiye Diyanet Vakfı İlâm Ansiklopedisi, (ìstanbul: TDV Yayınları, 1999), 19/445-446. Onun Hıristiyan hekimlerin dinî hayatı hakkında bilgi verdiği de anlaşılmaktadır. Bkz. Saim Yılmaz, Fatımatüz Zehra Kamacı Pekgeçgil, Levent Öztürk. "The Religious Life of the Christian Physicians according to Ibn Abu Usaybia", 39th International Congress on the History of Medicine, Bari-Italya, 5-10 Eylül 2004, 1: 152.

105 Eserin muhtevası hakkında bkz. Abdülkerim Özaydın, "Kitâbü’r-Ravzateyn", Türkiye Diyanet Vakfı İslâm Ansiklopedisi, (istanbul: TDV Yayınları, 2002), 26/112-113.

106 Abdülkerim Özaydın, "İbnü'l-Esîr İzzeddin", Türkiye Diyanet Vakfı İslâm Ansiklopedisi, (İstanbul: TDV Yayınları, 2000), 21/26-27.

107 William'ın çağdaşı İbnü'l-Esîr'in nakline veya İslâm geleneğindekine benzer bir Bahîra hadisesi anlattığı şeklindeki bir yorum için bkz. Pearson, The Islamic World and the Latin East, 51-55. 
Kur'an Hz. Peygamber'in vefatından sonra Hz. Osman tarafından yazılmıştır. William, İslâm'ın sona ereceğini ve bütün Müslümanların yakında Hıristiyan olacağını iddia etmiştir. O, görüşlerini desteklemek için Kur'an'dan ve hadislerden nakillerde bulunduğu gibi yazılı ve sözlü olduğunu belirtmeksizin Müslüman âlimlerden de bilgi aktarmıştır. William gibi şahısların Kur'an ve Hz. Peygamber hakkında yazdıkları eserlerin ayrıntılı olarak incelenmesinde zaruret vardır. Zira William, hem bir misyoner hem bir diplomat ve hem de İslâm ve Hz. Peygamber hakkında yazdığı iki eserle Haçlı seferleri boyunca ve daha sonra Avrupa'da önemli bir misyon sahibi olmuştur. Onun bu dönemde yazdığı eserler, Avrupa'da Aydınlanma dönemine kadar İslâm ve Hz. Peygamber imajının oluşmasında ve devamında önemli bir kaynak özelliği taşımıştır. Doğu'da Müslümanlara yakın bir ortamda yaşamış olması onu farklı bir konuma getirmiştir. Bununla birlikte onun Kur'an veya Hz. Peygamber hakkında ileri sürdüğü bazı iddiaların Batı kaynaklarında tekrarlanmadığı da dikkat çekmektedir. Zira Ortaçağ'da Avrupa'daki İslâm düşmanlığına göre onun yargıları hafif kalmaktadır. Onun misyonerliği Müslümanlara ve İslâm'a karşı daha müsamahakâr bir tutum içinde olmasını gerektirmiş gözüküyor.

William, eserlerinde âyetlerle birlikte bazı rivâyetleri nakletmiştir. Ancak o, bunların kaynağı olarak bir şahıs ismi veya herhangi bir eser zikretmemektedir. Bu rivâyetlerin yazılı veya sözlü kaynağa dayandığı hakkında bir şey söylemek mümkün değildir. William, "Müs/üman âlimlerin dediğine göre" diyerek bazı bilgiler aktarmaktadır. İslâm’a dair yazılmış Batılı kaynaklarda görebildiğimiz kadarıyla genelde Müslüman idareciler dışında şahıs isimleri pek zikredilmemektedir. Batı'da “İslâm’ı kendi kaynaklarından öğrenme" düşüncesi güçlenene kadar bu tutum devam etmiştir.

Trablusşamlı William, bazı âyet ve hadisleri geleneksel İslâm anlayışının dışında yorumlamıştır. Bunların bir kısmı misyonerlik düşüncesiyle ve polemik maksadıyla art niyetli olarak yapılmıştır. Yine William başta olmak üzere İslâm coğrafyasında uzun süre kalarak misyonerlik yapan ve Müslüman âlimlerle teolojik tartışmalara giren şahısların anlattıkları bilgilerin çağdaşları Müslüman müelliflerin eserlerine yansıyıp yansımadığı da araştırma gerektiren önemli bir husustur. Ortaçağ'da misyonerlik faaliyetlerinin Müslümanların Hıristiyanlaştırılmasına etkisinin olmadığı genel olarak ifade edilmektedir. Ancak İslâm’ın yayılmasını ve Hıristiyanların İslâm'a geçmesini ne ölçüde etkilediği konusu ise Müslüman araştırmacıları beklemektedir. Misyonerlik çalışmaları ve polemik türü eserler, Hıris- 
tiyanların dinlerini korumalarında etkili olmuştur. Müslümanların başka dillerde İslâm'ı anlatan eserler kaleme alma veya İslâm karşıtı eserlere o dillerde cevap vermeyi düşünmemiş olmaları da büyük bir boşluk oluşturmuştur.

Haçlı devletleri olarak bir süre Batılı Hıristiyanların hâkimiyetinde bulunan bölgelerde yaşayan veya Haçlı seferlerine katılanların yazdığı eserlerde İslâm ve Müslümanlar hakkında doğru bilgiler olduğu gibi yanlış bilgiler de bulunmaktadır. Bu dönemde aynı bölgelerde veya civar şehirlerde yaşamış olan İslâm âlimlerinin eserlerinde bu şahıslarla münasebetlerden söz edilip edilmediği, teolojik tartışmaların yapılıp yapılmadığına dair ayrıca araştırmalara ihtiyaç vardır.

William, Bahîra, Kur'an'ın kaynağı, cem'i, çok evlilik gibi bazı konularda İslâm, Doğu ve Batı Hıristiyan kaynaklarını ve hayal gücünü kullanarak âdeta yeni efsaneler oluşturmuştur. Onun gibi ister misyonerlik, seyahat veya hac düşüncesiyle İslâm dünyasında bulunmuş kişiler, isterse Doğu veya Batı/Latin Hıristiyan camiasına mensup olup İslâm, Kur'an ve Hz. Peygamber hakkında eser yazmış olan kişiler hakkında biyografik ve bibliyografik araştırmaların yapılması çağdaş oryantalizmi anlamak için elzem gözükmektedir.

\section{Kaynakça}

Apaydın, Mehmet. Siyer Kronolojisi. İstanbul: Kuramer Yayınları, 2018.

Arslan, İhsan. "Vahiy Bağlamında Rahib Bahîrâ Olayı́nın Değerlendirilmesi". Recep Tayyip Erdoğan Üniversitesi Sosyal Bilimler Dergisi 8 (2018): 313-341.

Bahkou, Abjar. "The Monk Encounters the Prophet-The Story of the Encounter between Monk Bahira and Muhammad as it is Recorded in the Syriac Manuscript of Mardin 259/2". Cultural and Religious Studies 3/6 (Nov.-Dec. 2015): 349-357.

Bobzin, Hartmut. Der Koran im Zeitalter der Reformation Studien zur Frühgeschichte der Arabistik und Islamkunde in Europa. Würzburg: Ergon Verlag, 2008.

Cesare, Michelina Di. "On Relics and Mausoleums: The Death of the Prophet Muhammad between History and Legend in the Mediterranean Context". Propaganda and (un)covered identities in treatises and sermons: Christians, Jews, and Muslims in the premodern Mediterranean. ed. Cándida Ferrero Hernández \& Linda G. Jones. Bellaterra: Universitat Autònoma de Barcelona Servei de Publicacions, 2020.

Cesare, Michelina Di. The Pseudo-Historical Image of the Prophet Muhammad in Medieval Latin Literature: A Repertory. Berlin: De Gruyter, 2012.

Cesare, Michelina Di. "New Sources for the Legend of Muhammad in the West" East and West 58 (2008): 9-31.

Çap, Sabri. Goldziher Öncesi Oryantalizm ve Hadis. Ankara: Illahiyat Yayınları, 2019.

Çap, Sabri. “Misyoner ve Oryantalist William of Tripoli'nin İslâm ve Hz. Peygamber Hakkındaki İki Eserinin Değerlendirilmesi". Dokuz Eylül Üniversitesi Ilahiyat Fakültesi Dergisi 52 (2020). 
Dawczyk, Maciej (Łódź). "The Image of Muhammad in Riccoldo da Monte di Croce's Contra legem Sarracenorum". Studia Ceranea 9 (2019): 391-405.

Demir, Halis - Recep Tayyip Gedikli - Mikail Şeker. "İslam Tarihindeki Bir Vakanın Yorum Kritiği: Rahip Bahira Olayı". Ağrı İslâmi llimler Dergisi 2 (2018): 57-92.

Ekkehart, Rotter. "Mohammed in der Stadt Die Erkenntnis um die Stadt Medina und das dortige Prophetengrab im mittelalterlichen Europa". Zeitschrift für historische Forschung, 36 (2009): 183233.

Engels, Peter. "Wilhelm von Tripolis: De Statu Sarracenorum, Bemerkungen zu einem Neuen Textfund". Zeitschrift der Deutschen Morgenländischen Gesellschaft. Supplement VIII: XXIV. Deutscher Orientalistentag, (1988): 77-89.

Engels, Peter. Wilhelm von Tripolis Tractatus de statu Sarracenorum et de Mahomete pseudopropheta et eorum lege et fide; Notitia de Machometo De statu Sarracenorum. Kommentierte lateinisch-deutsche Textausgabe. Würzburg- Echter: Altenberge- Oros Verlag, 1992.

Esen, Salihe. Dominiken Tarikatı ve Katolik Kilisesi'ndeki Yeri. Ankara: Ankara Üniversitesi, Sosyal Bilimler Enstitüsü, Doktora Tezi, 2015.

Gottheil, Richard James Horatio. "A Christian Bahira Legend". Zeitschrift für Assyriologie, 13 (1898): 189-210; 14 (1899-1900): 203-268; 15 (1901): 56-102; 17 (1903): 125-166.

Griffith, Sidney H.. "Muhammad and the Monk Bahīrā: Reflections on a Syriac and Arabic Text from Early 'Abbāsid Times. Oriens Christianus, 79 (1995): 146-174.

Kamacı, Fatımatüz Zehra. Bir Hıristiyan Bahîrâ Efsanesi -Bir TahrifÖrneği (XI-XII. Yüzyıl). İstanbul: İnkılab Yayınları, 2008.

Kaya, Mahmut. "İbn Ebû Usaybia”, Türkiye Diyanet Vakfı İslâm Ansiklopedisi, 19/445-446. İstanbul: TDV Yayınları, 1999.

Klueting, Edeltraud. "Quis fuerit Machometus? Mohammed im lateinischen Mittelalter (11.-13. Jahrhundert)". Archiv für Kulturgeschichte 90 (2008): 283-306.

Kurt, Abdülkadir. "Hristiyanlık Tarihinde Fransisken Tarikatı". Yüksek Lisans Tezi, Necmetttin Erbakan Üniversitesi, 2012.

Kutluay, İbrahim. "Oryantalistik Düşünceye Etkisi Açısından Haçlı Seferleri”. Eyyûbîler'de Siyasi ve Ekonomik ilişkiler. ed. Abdulhalim Oflaz, Rumeysa Seven vd. İstanbul: Hiperlink Yayınları, 2020.

Külekçi, Cahit. “Ermeni Kaynaklarında Siyer Anlatıları-Movses Dasxurants'i'nin Tarihi Örneği-". Akademik Siyer Dergisi I/1 (2020): 140-154.

Möhring, Hannes. Der Weltkaiser der Endzeit: Entstehung, Wandel und Wirkung einer tausendjährigen Weissagung. Stuttgart: Jan Thorbecke Verlag, 2000.

Munro, Dana Carleton. "The Western Attitude Toward Islam During the Period of the Crusades". Speculum A Journal of Mediaeval Studies 6/3 (July, 1931): 329-343.

Özaydın, Abdülkerim. "İbnü'l-Esîr İzzeddin". Türkiye Diyanet Vakfı İslâm Ansiklopedisi. 21/26-27. İstanbul: TDV Yayınları, 2000.

Özaydın, Abdülkerim. "Kitâbü'r-Ravzateyn". Türkiye Diyanet Vakfı İslâm Ansiklopedisi. 26/112-113. İstanbul: TDV Yayınları, 2002.

Pearson, Jeremy Daniel. "The Islamic World and the Latin East: William of Tripoli and his Syrian Context". PhD diss., University of Tennessee, Knoxville (ABD), 2018.

Prutz, Hans. Kulturgeschichte der Kreuzzüge. Berlin: Königliche Hofbuchhandlung, 1883. 


\section{Sabri ÇAP}

13. Asır Misyoner ve Oryantalistlerinden William of Tripoli'nin Hz. Peygamber ve Kur'an Hakkındaki Görüşlerinin Tahlil ve Tenkidi

Raeder, Siegfried. Antworten auf den Islam, Texte christlicher Autoren vom 8. Jahrhundert bis zur Gegenwart. Neukirchen: Neukirchener Verlag, 2006.

Roggema, Barbara. "A Christian Reading of the Qur'an: The Legend of Sergius-Bahira and its Use of Qur'an and Sira". Syrian Christians under Islam the First Thousand Years. ed. David Thomas. 57-73. Leiden: Brill, 2001,

Roggema, Barbara. The Legend of Sergius Bahira Eastern Christian Apologetics and Apocalyptic in Response to Islam. Leiden - Boston: Brill, 2009.

Roggema, Barbara. "Salvaging the Saintly Sergius: Hagiographical Aspects of the Syriac Legend of Sergius Bahīrā". Entangled Hagiographies of the Religious Other. ed. Alexandra Cuffel ve Nikolas Jaspert. 55-83. Newcastle: Cambridge Scholars Publishing, 2019.

Sprenger, Aloys. "Mohammad's Zusammenkunft mit dem Einsiedler Bahyrâ". Zeitschrift der Deutschen Morgenländischen Gesellschaft 12 (1858): 238-249.

Szilagyi, Krisztina. "Muhammad and the Monk: the Making of the Christian Bahira Legend". Jerusalem Studies in Arabic and Islam 34 (2008): 169-214.

Tolan, John Victor. Saracens: Islam in the Medieval European Imagination. New York: Columbia University Press, 2002.

Wilhelm von Tripolis. Notitia de Machometo. Hrsg. Peter Engels, Würzburg- Altenberge: Echter Verlag, Oros Verlag, 1992.

Wilhelm von Tripolis. De statu Sarracenorum. Hrsg. Peter Engels, Würzburg- Altenberge: Echter Verlag, Oros Verlag, 1992 (Engels iki eseri birlikte yayınlamıştır).

Yılmaz, Saim, Fatımatüz Zehra Kamacı Pekgeçgil ve Levent Öztürk. "The Religious Life of the Christian Physicians according to Ibn Abu Usaybia". 39th International Congress on the History of Medicine. Bari-Italya, 5-10 Eylül 2004, ed. Alfredo Musajo-Somma, 541-545. 
